\title{
Podhale Palaeogene Flysch as geotouristic attractive region - first look to its unique geological values
}

\author{
Paleogeński flisz podhalański jako atrakcyjny region geoturystyczny - pierwsze \\ spojrzenie na jego unikalne walory geologiczne
}

\author{
Michał Krobicki \& Jan Golonka \\ AGH University of Science and Technology, Faculty of Geology, Geophysics and Environmental Protection, \\ Al. Mickiewicza 30, 30-059 Kraków \\ e-mail:krobicki@geol.agh.edu.pl,jan_golonka@yahoo.com
}
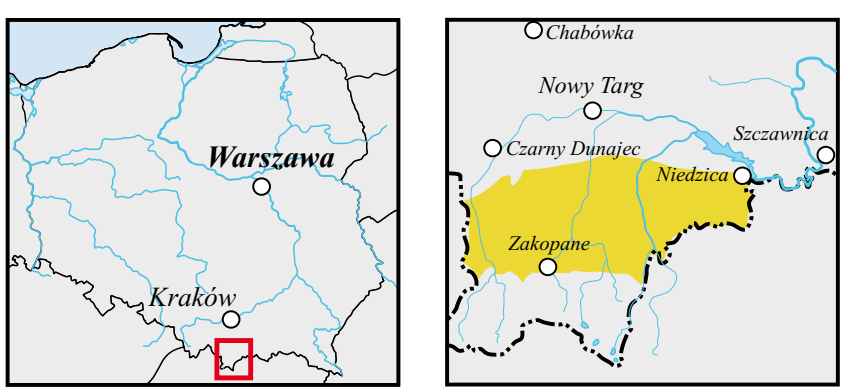

Abstract: The primary aim of this paper is note the attention to geological phenomena in the Podhale Flysch region, and especially lithological differentiation of flysch rocks, their sedimentological features, tectonic structures, stratigraphical and palaeontological aspects, and all of these according to recent regional position of Podhale and its palaeogeographical history in wider geodynamic context. Authors summarized the newest knowledge about geological history of the Podhale Flysch region and presented its geotouristic potential in one of the beautiful place in southern Poland. Short reviews of several aspects of geological works have been made according to: sedimentology, biostratigraphy, petrography and mineralogy, structural geology, organic geochemistry, palaoentology and palaeoecology, palaeogeography and basin analysis, geophysics, geothermy, Quaternary geology and geomorphology, inanimate nature protection and geotourism. In fact, the Podhale Flysch region is good place for geological education and promotion of Earth sciences.

Key words: Polish Carpathians, Podhale Palaeogene Flysch, palaeogeography, geotouristic attractions

Treść: Podstawowym celem niniejszej pracy jest zwrócenie uwagi na geologiczne fenomeny fliszu podhalańskiego, a szczególnie zróżnicowanie utworów fliszowych regionu, ich sedymentologicznych cech, struktur tektonicznych, aspektów stratygrafii i paleontologii, a one wszystkie $w$ nawiqzaniu do dzisiejszej, regionalnej pozycji Podhala i jego paleogeograficznej historii w szerszym geodynamicznym kontekście. Autorzy podsumowali najnowsza wiedze na temat geologicznej historii fliszu podhalańskiego i zaprezentowali jego geoturystyczny potencjat wjednym z najpiękniejszych miejsc Polski południowej. Przedstawiono krótki przeglad wielu aspektów prowadzonych tutaj prac geologicznych z: sedymentologii, biostratygrafii, petrografi $i$ mineralogii, geologii strukturalnej, geochemii organicznej, paleontologii i paleoekologii, paleogeografii i analizy basenów, geofizyki, geotermii, geologii czwartorzędu i geomorfologii, ochrony przyrody nieożywionej i geoturystyki. Zdecydowanie, rejon fliszu podhalańskiego jest dobrym miejscem dla edukacji geologicznej i promocji nauk o Ziemi.

Słowa kluczowe: Polskie Karpaty, paleogeński flisz podhalański, paleogeografia, atrakcje geoturystyczne

\section{Introduction}

Podhale region is very attractive area for tourists both by its close connection to Tatra Mts on the one, southern side, and to the Pieniny Mts on the opposite, northern side. Such geographical position of this region is useful to visit both mentioned regions, which are prime geotouristic attractions in southern Poland (Krobicki \& Golonka, 2008). But Podhale area with gentle hills, wild forests, clean rivers and streams and perfect landscapes to both, southern and northern directions, offers also high spectacular inanimate nature objects of our Carpathians, by study of Palaeogene flysch deposits. Maybe first impression indicates very monotonous sequences of flysch-type rocks, but several features of these sedimentary units and their tectonic regimes surprisingly give us introduction to understanding complicated history of the origin of the Podhale Palaeogene Flysch.

The primary aim of this paper is to describe geological phenomena in this region, especially lithological differentiation of flysch rocks, their sedimentological features, tectonic architecture, stratigraphical and palaeontological aspects. All

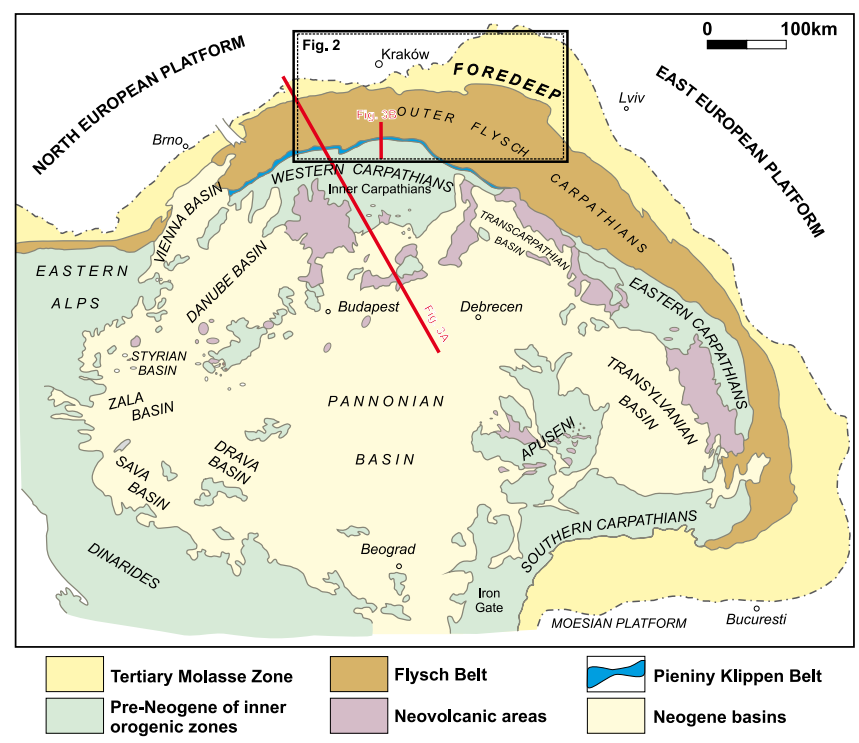

Fig. 1. Tectonic sketch map of the Alpine-Carpathian-PannonianDinaride basin system (modified after Kováč et al., 1998; Plašienka et al., 2000) • Szkic tektoniczny regionu alpejsko-karpacko-panońsko-dynarydzkiego (zmodyfikowano według Kováč et al., 1998; Plašienka et al., 2000) 


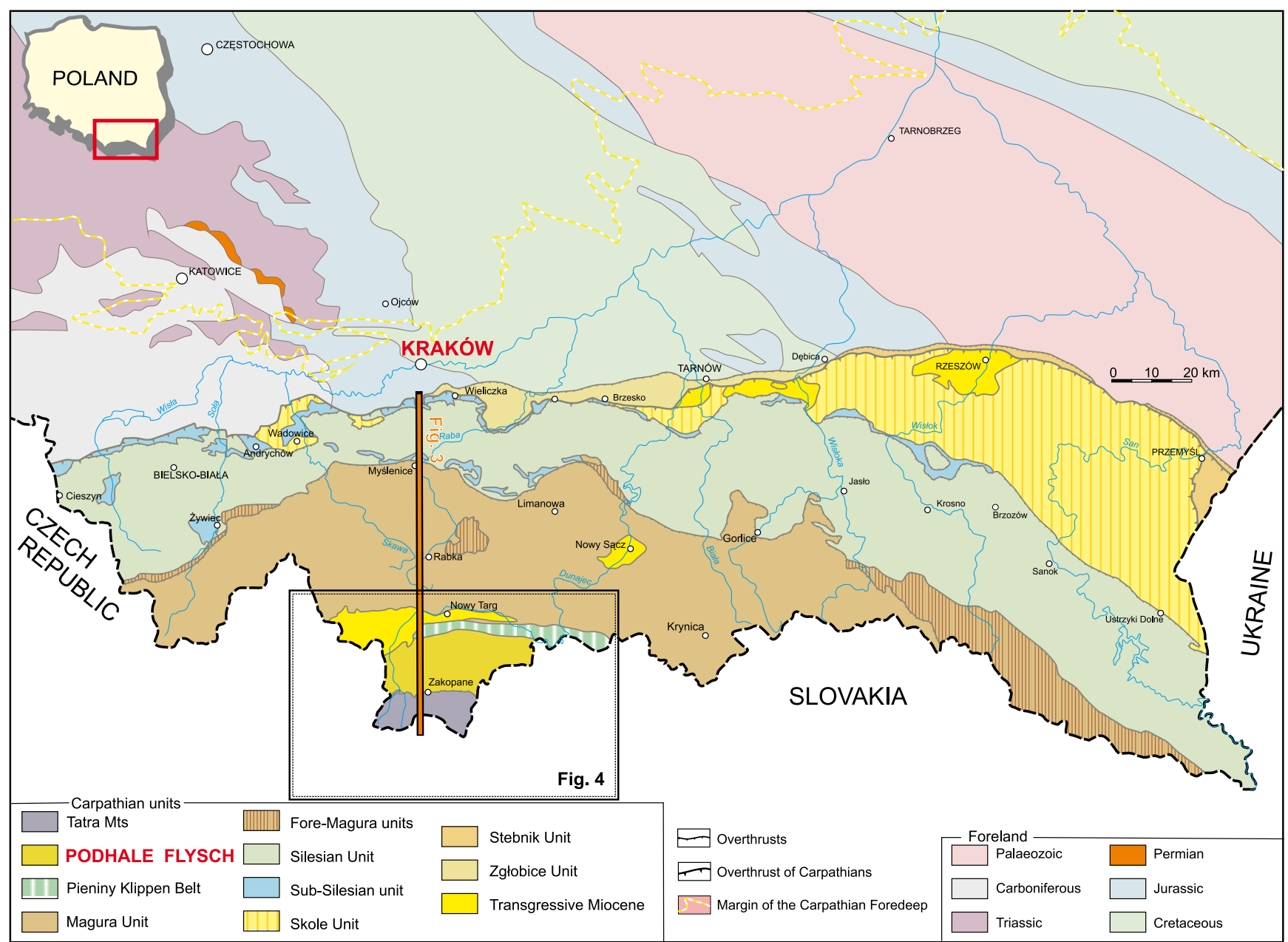

Fig. 2. Geological map of the Polish Carpathians, Carpathian Foredeep and Foreland (after Żytko et al., 1989; simplified) with general cross-section across Carpathians (Fig. 3) - Mapa geologiczna polskich Karpat, Zapadliska Przedkarpackiego i ich przedpola (wg Żytko et al., 1989; uproszczono) z lokalizacją generalnego przekroju przez Karpaty (Fig. 3)

of these features are linked to the general regional position of Podhale and its palaeogeographical history in wider geodynamic context.

The Palaeogene is subdivided to two parts in the Podhale region. Older is represented by the so-called "Tatra Eocene" (Middle-Upper Eocene) and consists of conglomerates (Passendorfer, 1983) and carbonate rocks (nummulitic limestones) (Roniewicz, 1969, 1979; Bac-Moszaszwili et al., 1979; Kulka, 1985; Bartholdy et al., 1999). Younger complex (Oligocene) is represented by flysch deposits (the Podhale Flysch). A stratigraphical gap is suggested between the "Tatra Eocene" and the overlying flysch deposits (Gedl, 2000a). According to Olszewska \& Wieczorek (1998) the whole Palaeogene deposits in Podhale region represent four distinct facies: the Middle Eocene basal conglomerates originated as deltaic and cliff-type facies (0-100 $\mathrm{m}$ in thickness), the Upper Eocene sublittoral nummulitic limestones of carbonate platform (max. 100-150 m), the uppermost Eocene hemipelagic marls with planktic foraminifera (ca. $20 \mathrm{~m}$ ), and the Oligocene flysch as typical turbiditic sedimentation with coarsening upward sequence (2700-3400 m).

The Podhale Palaeogene Flysch belongs to larger unit, so-called Central Carpathian Palaeogene Basin (Marschalko, 1987), which lies within the West Carpathian Mountain chain
(Fig. 1) (Soták \& Janočko, 2001; Soták et al., 2001; Golonka et al., 2005a with literature cited therein). Polish part of this basin was filled mainly by very thick sequence of flysch-type rocks, comprising up to ca. $3400 \mathrm{~m}$ of conglomerates, sandstones, mudstones and siltstones of turbiditic submarine fans origin (Westfalewicz-Mogilska, 1986; Marschalko, 1987; Wieczorek, 1989; Soták \& Janočko, 2001). In polish nomenclature this region was classically termed as the Podhale Flysch (Radomski, 1958). Recently it occurs between Pieniny Klippen Belt (on the north) and Tatra Mts (on the south) (Figs $2-5$ ). Flyschoidal rocks occupied depression and built wide synclinal structure (Figs 3, 5).

\section{Palaeogeography and location of the Podhale Basin}

The Podhale Basin is considered as a fore-arc basin, located at the NE border of the North Pannonian unit, probably developed above a B-subduction zone of the European plate (Tari et al., 1993). Eocene volcanic rocks around the Balaton lineament in Hungry indicate some possibilities of connection with this subduction. Some palaeogeographical reconstruction suggested that Central Carpathian region has been located some hundreds kilometers to the southwest of its present 


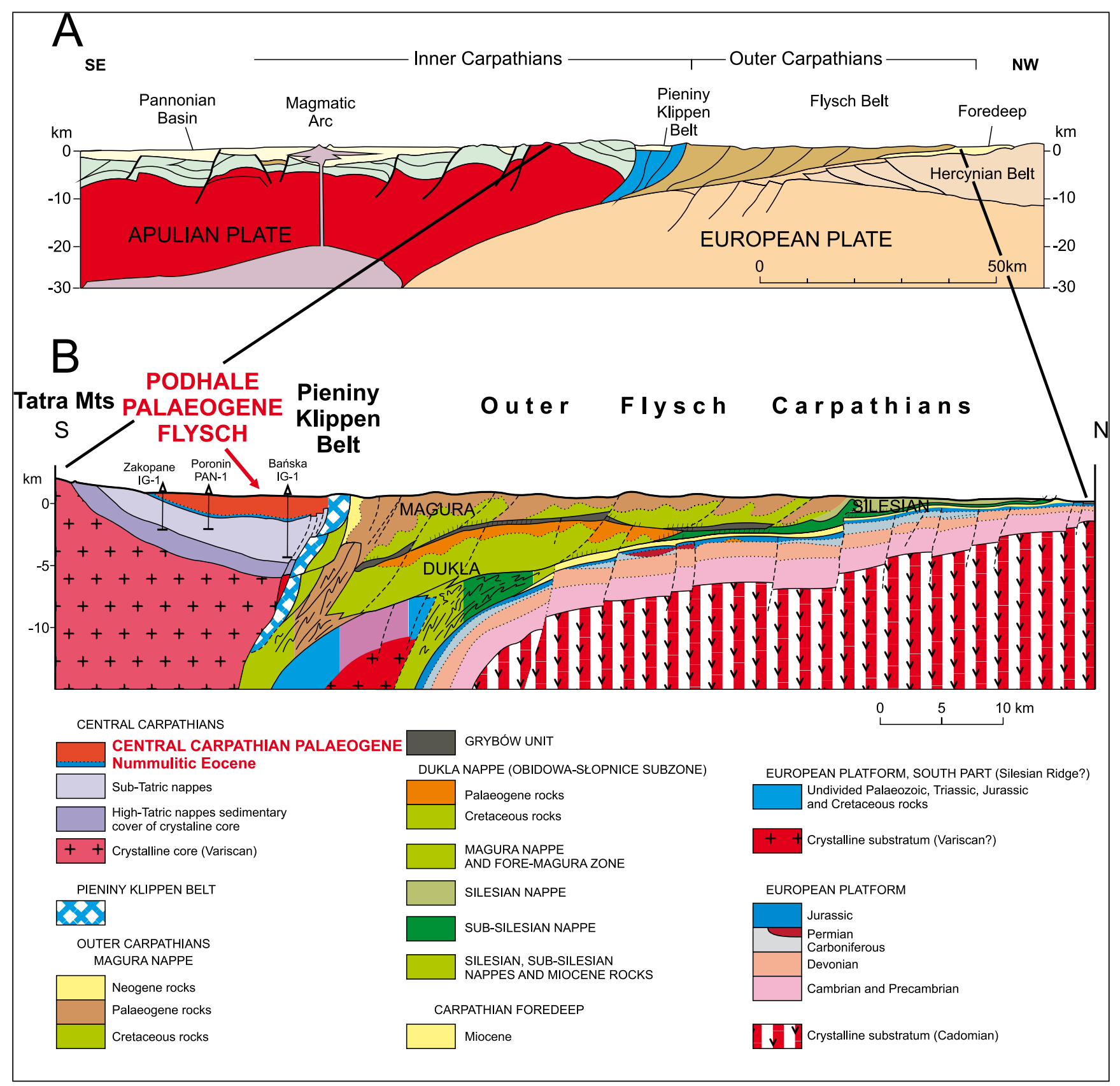

Fig. 3. Generalized cross-sections across Carpathian-Pannonian region (A) (after Picha, 1996) and Polish Carpathians (B) (after Golonka et al., 2005 -Zgeneralizowane przekroje przez obszar Karpacko-Panoński (A) (wg Picha, 1996) oraz polskie Karpaty (B) (wg Golonka et al., 2005)

position (Csontos et al., 1992). During the Oligocene time the convergence between Africa and Eurasia took place (Fig. 6). The tectonic collision of the Apulia and the North European platform (Eurasia in general sense) (Figs 6-8) has been the main process resulted in transport of several plates in AlpineCarpathian system. From the global and European point of view it was connected with plate's reorganization during the Alpine orogeny and geodynamic reaction to the origin and movements of several accretionary prisms in Alpine-Carpathian arc (Golonka, 2004) (Figs 6-8). In this time metamorphism of the Penninic nappes in the Alps reached peak thermal conditions at about $30 \mathrm{Ma}$ (Kurz et al., 1996). The Paratethys Sea was formed in Europe and Central Asia, ahead of the northward moving orogenic belts (Dercourt et al., 1993).
The Paratethys Sea included orogenic foredeep as well as remnants of older oceanic basins and epicontinental platforms of the Peri-Tethys area. There was a transition from flysch to molasse type of sedimentation in the basins in the AlpineCarpathian realm (Golonka, 2004). A little bit later, during the Miocene times, collisions continued in the area between Africa and Eurasia. Apulia and the Alpine-Carpathian terranes were moving northwards, colliding with the European plate, until $17 \mathrm{Ma}$ (Decker \& Peresson, 1996). This collision caused the foreland to propagate north. The north to NNWvergent thrust system of the eastern Alps was formed. Oblique collision between the North European plate and the overriding western Carpathian terranes led to the development of an outer accretionary wedge, the build-up of many flysch nappes 

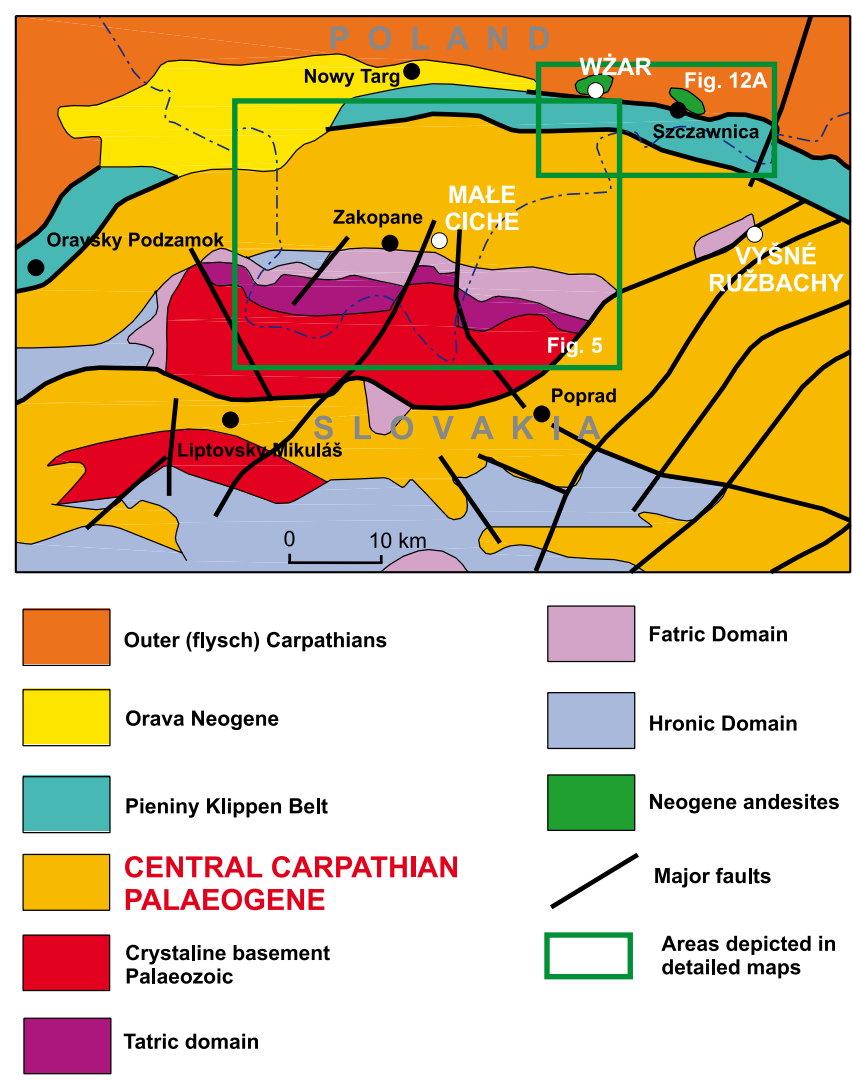

Fig. 4. Simplified geological sketch of southernmost Poland/northernmost Slovakia with main geological units and location of field trip stops (see - Środoń, this volume) • Uproszczony szkic geologiczny polsko-słowackiego pogranicza z głównymi jednostkami geologicznymi i lokalizacją punktów wycieczki terenowej (patrz - Środoń, ten zeszyt)

(Outer Flysch Carpathians - Figs 1-3) and the formation of a foredeep (Kováč et al., 1998; Ślączka, 1996). These nappes were detached from their original basement and thrust over the Palaeozoic-Mesozoic deposits of the North European platform (Figs 1-3). This process was completed during the Late Miocenes time in the area of the Vienna Basin and then progressed northeastwards (Oszczypko, 1999; Golonka et al., 2004, 2006b).

The Podhale region is the northern part of the Central Carpathian Palaeogene Basin, which includes Liptov, Orava and Spiš depressions. It is built up of Palaeogene strata underlain by mostly calcareous Mesozoic rocks. The lithostratigraphic section of these deposits has been recognized by several deep boreholes (Fig. 3). In subsequent years, the boreholes provided very advantageous information. The results of investigations showed that the sub-Palaeogene substratum is an extension of geological-structural elements of the Tatra massif, to which the Sub-Tatric (Krížna, Choč) and High-Tatric nappes belong. It is generally accepted, based on different evidences both from the field and boreholes, that the Tatra Mts have been covered by the Podhale Palaeogene flysch deposits, later eroded during the uplift of the Tatra massif. Moreover, in logs of some deep drillings (Sokołowski, 1973; Chowaniec, 1989) the facies elements similar to certain rock types of the Pieniny successions and deposits of uncertain affinity were found. After the retreat of the Late Cretaceous sea, a subsequent transgression took place in the Middle Eocene that resulted in the formation of conglomerates and limestones in the initial phase. These deposits form the basal member of the Podhale Palaeogene. Then, typical flysch deposits were formed. Sediments of the calcareous Eocene are known from numerous natural exposures situated at the outlets of valleys draining the Tatra Mts and from drillings made in the Podhale Basin. Stratigraphically younger of the Palaeogene, i.e. the Podhale flysch occur directly on the transgressive deposits of the calcareous Eocene. The largest thickness of the Podhale flysch, ca. $3000 \mathrm{~m}$, was recorded in borehole Chochołów PIG-1 (Golonka et al., 2005a).

In the Slovak Orava, the Eocene-Oligocene sequence is known as the Podtatranská Group (Gross et al., 1984, 1993), which is an equivalent of the Podhale Flysch in Poland. The basal Borové Formation lies transgressively on the Mesozoic cover of the Malá Fatra, Tatra, and Choč mountains. The lithology of this formation is variable, being strongly dependent on the character of the substratum upon which it was deposited. It is composed of breccias, sandstones, and carbonates, sporadically with large foraminifers. The thickness of the entire formation varies from few centimetres to several tens of metres. The Szaflary beds, occurring in the northern part of the basin (Fig. 5), are generally assigned to the oldest flysch members (Kępińska, 1997; Chowaniec \& Kępińska, 2003). Shaly flysch strata of the Zakopane beds, in turn, belong to the younger members. The Slovak equivalent of the Zakopane beds is the Huty Formation, which comprises mainly pelitic, sandstone (also some breccias) strata, only few centimeters thick, in contrast to several tens of centimetres to metres thick clayey beds. Localities exposing dark-brownish Menilite-like silty claystones occur at several places within the Huty Formation. The Chochołów beds (Zuberec Formation in Slovakia), overlying the Zakopane beds, is of typical flysch facies, with variable sandstone/shale ratio. Fine-grained breccias and even slumped conglomerates are common. Submarine slumps are of sandy matrix with dispersed clasts of sandstones, siltstones, claystones, and limestones. The total thickness of this unit is about 500-900 m, and its age was determined as the Early Oligocene (Gedl, 1999a, 2000a) (by Slovakian geologists as Late Eocene to Early Oligocene Gross et al., 1993). The uppermost formation in the Podtatranská Group in Slovakia is the Biely Potok Formation. Its equivalent in Poland is known as the Ostrysz beds, forming the culmination of Ostrysz Mt in the western Podhale (Fig. $5)$. This formation consists of coarse-grained sandstones and subordinate claystone strata. The sandstones are mainly siliciclastic with clayey matrix, bearing only small percentage of carbonates. The thickness of the Biely Potok Formation is up to $700 \mathrm{~m}$, and its age is Late Oligocene. At few places (in Slovakia only), the Pucov Conglomerates occur (e.g. south of the Oravský Podzámok). This member consists of blocky conglomerates bearing various Mesozoic carbonate clasts cemented with reddish sandy-pelitic matrix. Longitudinal, narrow bodies of conglomerates are incised into the Zuberec and Huty formations, and also to the Mesozoic substratum. The Pucov Conglomerate is interpreted as a channel fill supplied from the nearby southern source. The thickness of 170 m was documented by a borehole log (Gross et al., 1993). 

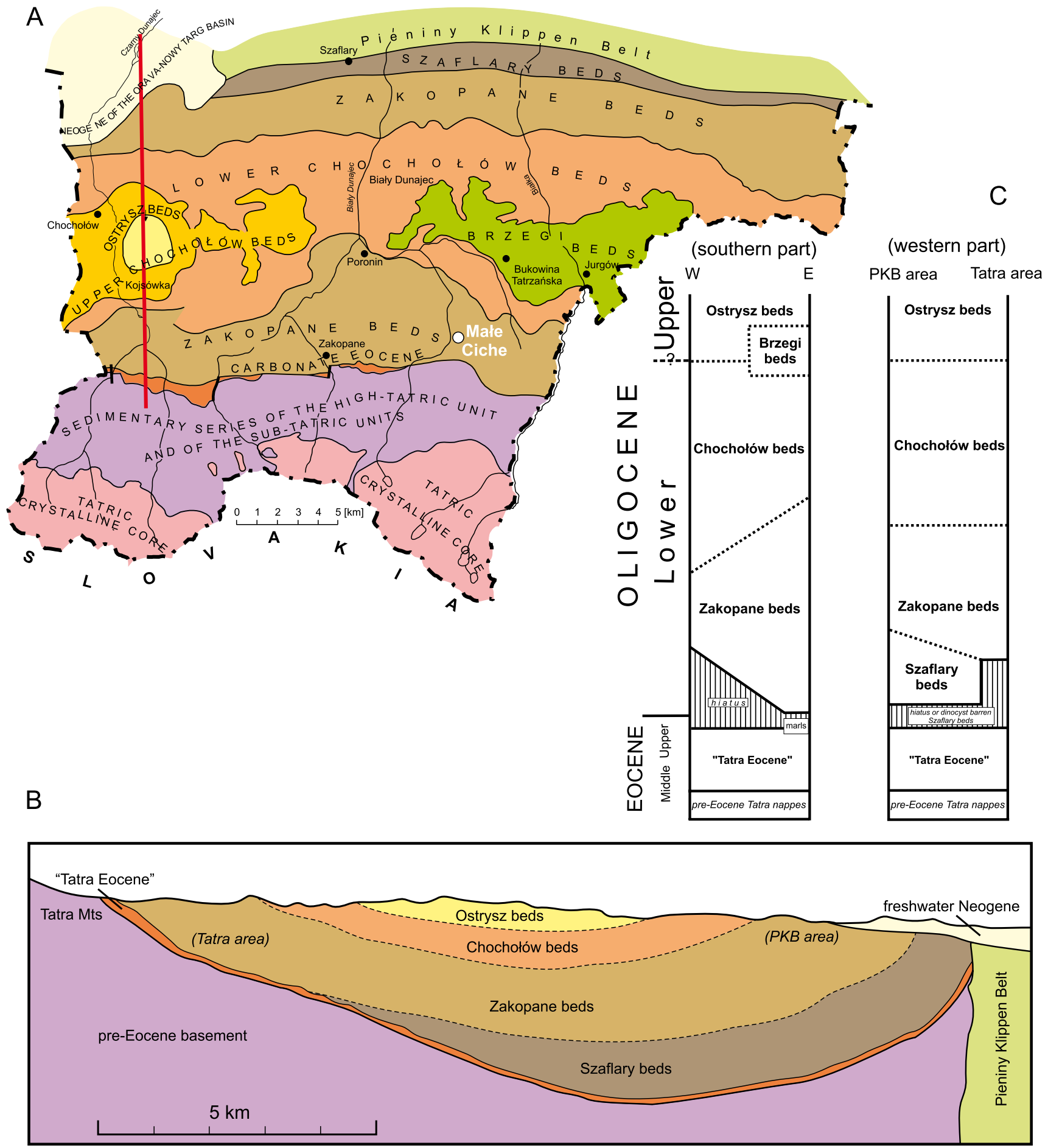

Fig. 5. Geological sketch of the Tatra Mts and the Podhale Palaeogene Flysch (A) with marked of cross section (red line) (after Chowaniec, 1989; Chowaniec \& Kępińska, 2003; slightly modified), cross section by western part of area (B) (after Gedl, 2000a), and lithostratigraphy of the Podhale Palaeogene (C) (after Gedl, 2000a) • Szkic geologiczny Tatr i paleogeńskiego fliszu podhalańskiego (A) z zaznaczona linią przekroju (czerwona kreska) (wg Chowaniec, 1989; Chowaniec \& Kępińska, 2003; nieco zmienione), przekrój przez zachodnią część obszaru (B) (wg Gedl, 2000a) i litostratygrafia paleogenu podhalańskiego (C) (wg Gedl, 2000a)

Palaeogeographical position of the Podhale Palaeogene Basin is showed in global, European and Carpathian perspectives (Figs 6-8) with full geodynamic context and facies distribution during the Oligocene times. Janočko \& Kováč (2003; see also references therein) suggested that the initial evolutionary stage of the basin was due to oblique convergence during the retreat of subduction boundary, which resulted in compressional regime in front of the advancing upper plate and extension in the plate's inner part. The opening of the Central Palaeogene Basin was related to this extension. The front of the Inner Carpathian plate served as a source area for sedimentation of the Szaflary beds. In the presently narrow zone along the Pieniny Klippen Belt, the Palaeogene strata were deformed into slices and folds (Fig. 9A-C). The wide 


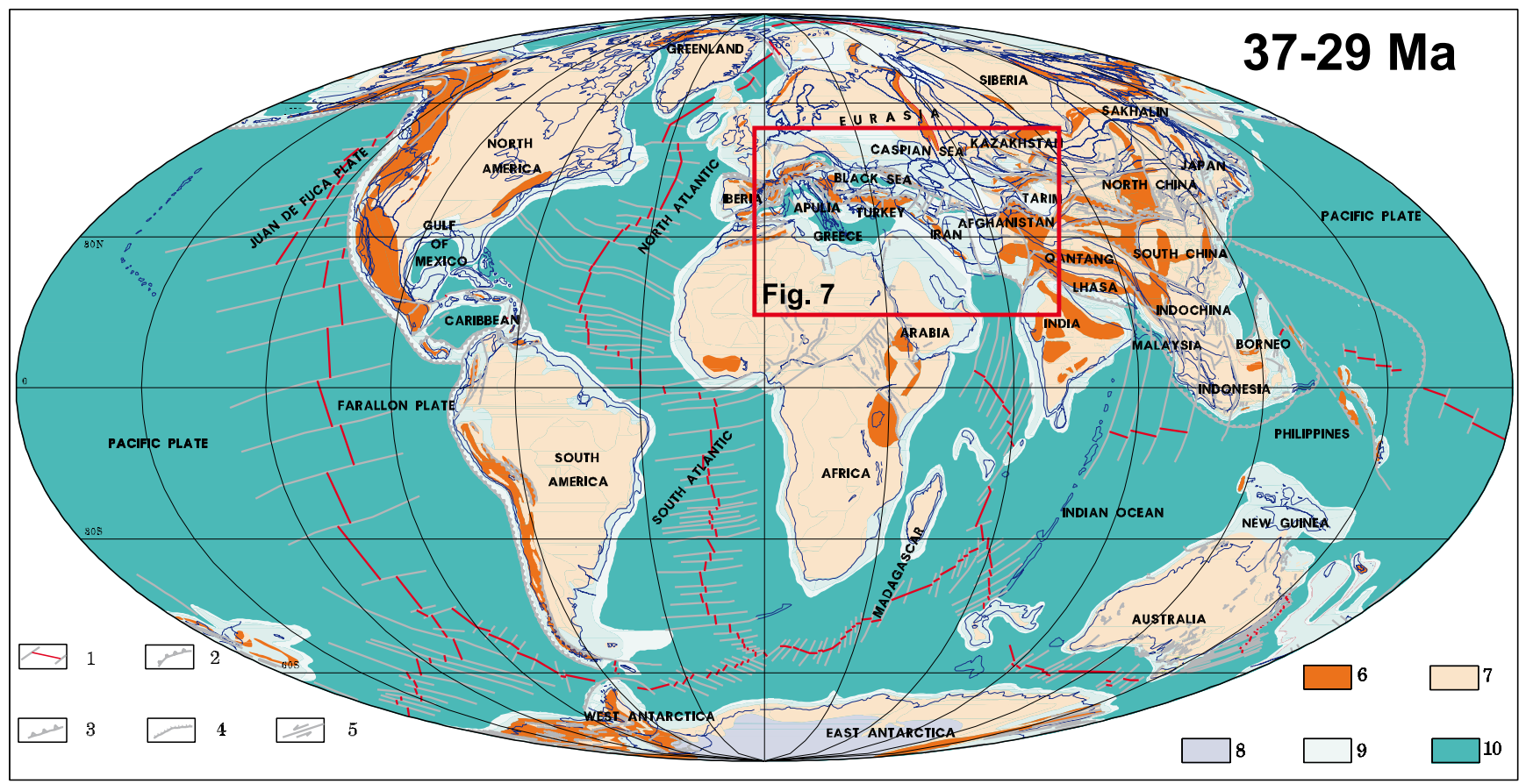

Fig. 6. Global plate tectonic map of the Oligocene. Explanations: 1 - oceanic spreading center and transform faults; 2 - subduction zone; 3 - thrust fault; 4 - normal fault; 5 - transform fault; 6 - mountains; 7 - landmass; 8 - ice cap; 9 - shallow sea and slope; 10 - deep ocean basin (from Golonka, 2000; Golonka et al., 2006a; modified) • Globalna mapa tektoniki płyt litosfery w oligocenie. Objaśnienia: 1 - centrum spredingu oceanicznego i uskoki transformujące; 2 - strefa subdukcji; 3 - uskok nasuwczy; 4 - uskok normalny; 5 - uskok transformujący; 6 - góry; 7 - lądy; 8 - czapa lodowa; 9 - płytkie morze i skłon kontynentalny; 10 - głęboki ocean (wg Golonka, 2000; Golonka et al., 2006a; zmienione)

area $(15-20 \mathrm{~km}$ ?) of the northern rim of the Inner Carpathian Palaeogene is missing. It is that part, where the lateral input of the material from the source had produced proximal sediments. One has to bear in mind, however, that palaeomagnetic data point to significant $\left(70-110^{\circ}\right)$ counterclockwise rotations within the Carpathian Palaeogene Basin (see, e.g. Grabowski \& Nemčok, 1999; Márton, 2003; Csontos \& Vörös, 2004; Golonka et al., 2005a). According to Golonka et al. (2005a), an analysis of exotic clasts supports this rotation, indicating that neither the present-day Tatricum nor the SubTatric (Križna and Choč) nappes were source areas for the Pieniny and Magura flysch during Palaeogene time. This question requires new independent research, but nevertheless it calls for a substantial correction in estimations of the genuine palaeogeographic location of alimentary areas. Perhaps the missing part of the Central Palaeogene Basin is located somewhere within the Tisza plate. The Transylvanian Palaeogene (e.g., Săndulescu et al., 1981; Ciulavu \& Bertotti; 1994; Meszaros, 1996) and certain parts of the Szolnok flysch Palaeogene sequences, situated in the marginal part of the Tisza unit (e.g. Nagymarosi \& Báldi-Beke, 1993), display similarities with the Central Carpathian Palaeogene. This problem requires further investigations. In the Neogene, the Inner Carpathian plate rotation wiper effect led to significant deformation along the plate boundary, which resulted in a complex tectonic pattern along the present-day boundary between the Central Carpathian Palaeogene and the Pieniny Klippen Belt. The present-day Podhale Basin is an asymmetric basin, delimited by the Tatras in the south, and by a steep fault along the Pieniny Klippen Belt in the north. According to Soták \& Janočko (2001), the structural pattern of the Central Carpathian Palaeogene Basin includes basementinvolving fault zones, like the Margecany and Muran faults. Extensional features, like half-grabens and listric and antithetic faults are to be found in the Hornad, Periklippen and Poprad Depressions, while structures related to retro-wedge thrusting, transform faulting, and strike-slip tectonics occur in the Šambron Zone (Mastella et al., 1988; Kovač \& Hók, 1993; Ratschbacher et al., 1993; Nemčok \& Nemčok, 1994; Marko, 1996; Sperner, 1996, 2002; Plašienka et al., 1997; Soták \& Janočko, 2001; Janočko \& Kováč, 2003).

The above-mentioned counterclockwise rotation of the Alcapa plate was compensated by dextral shearing in a transpressional zone between the Alcapa and North European plates (Ratschbacher et al., 1993; Soták \& Janočko, 2001). The present-day northern boundary was caused by amputation by a transform fault related to this rotation.

\section{Most typical features of the Podhale Palaeogene Flysch}

As we mentioned above, only in Slovakian part of the Central Carpathian Palaeogene system formal lithostratigraphical units exist. Pavol Gross and his co-authors (Gross et al., 1984) proposed to distinguished five units according to their lithological differentiation and stratigraphical position. These are (see also - Soták \& Janočko, 2001; Soták et al., 2001):

- Borové Formation - this formation of coarse-clastic deposits is mainly composed by sedimentary breccias, conglomerates, and carbonate sandstones and especially by organogenic and organodetrital nummulitic limestones. These types of rocks are overlying older, degraded pre-Eocene nap- 


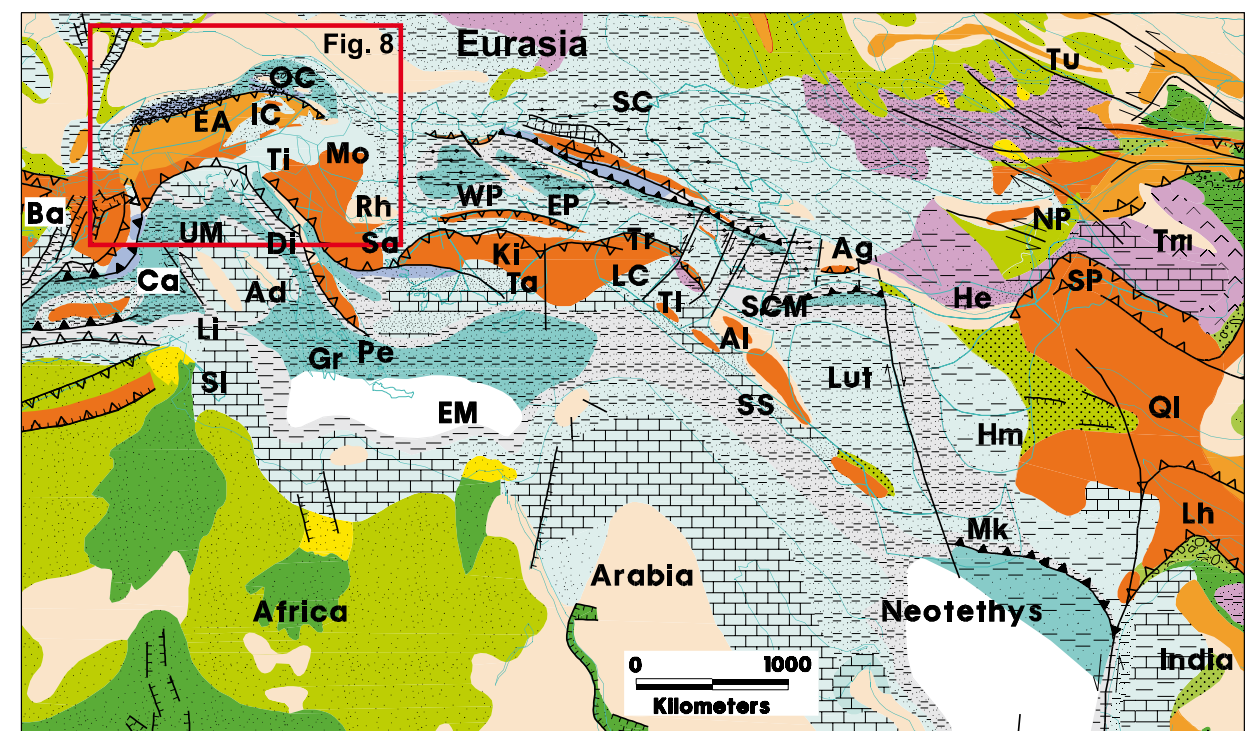

Fig. 7. Palaeogeography of the southern margin of Eurasia with lithofacies of the circum-Carpathian/ Caspian areas during Oligocene time (plates' position about $30 \mathrm{Ma}$ ) (after Golonka, 2004; slightly modified). Abbreviations of oceans/seas and plates names: Ad - Adria (Apulia); Ag - Aghdarband (southern Kopet Dagh); Al - Alborz; Ba - Balearic; Ca - Calabria-Campania; Di - Dinarides; EA -Eastern Alps; EM - Eastern Mediterranean; EP - Eastern Pontides; Gr - Greece; He - Heart; Hm - Helmand; IC - Inner Carpathians; Ki - Kirsehir; LC - Lesser Caucasus; Lh - Lhasa; Li - Ligurian (Piemont) Ocean; Mk - Makran; Mo - Moesia; NP - North Pamir; OC - Outer Carpathians; Pe - Pelagonian plate; Qi - Qiangtang; Rh - Rhodopes; Sa - Sakarya; SC - Scythian; SCM - South Caspian microcontinent; Sl - Sicily; SP - South Pamir; SS - Sanandaj-Sirjan; Ta - Taurus terrane; Ti - Tisa; Tl - Talysh; Tm - Tarim; Tr - Transcaucasus; Tu - Turan; UM - Umbria-Marche; WP - Western Pontides

Paleogeografia południowej części Eurazji z litofacjami obszaru wokółkarpacko-kaspijskiego w oligocenie (pozycja płyt litosfery - około $30 \mathrm{mln}$ lat temu) (wg Golonka, 2004; nieco zmienione). Objaśnienia skrótów: Ad - Adria (Apulia); Ag - Aghdarband (południowy Kopet Dagh); Al - Alborz; $\mathrm{Ba}$-Baleary; Ca-Kalabria-Kampania; Di-Dynarydy; EA - wschodnie Alpy; EM-wschodni obszar medyterrański; EP - wschodnie Pontydy; Gr - Grecja; He - Heart; Hm - Helmand; IC - Karpaty Wewnętrzne; Ki - Kirsehir; LC - Kaukaz Mniejszy; Lh - Lhasa; Li - ocean liguryjski (piemoncki); Mk - Makran; Mo - płyta mezyjska; NP - Pamir północny; OC - Karpaty Zewnętrzne; Pe - płyta pelagońska; Qi - Qiangtang; Rh - Rodopy; Sa - Sakarya; SC - płyta scytyjska; SCM - mikrokontynent południowego Morza Kaspijskiego; Sl - Sycylia; SP - Pamir południowy; SS - Sanandaj-Sirjan; Ta - terran Gór Taurus; Ti - płyta Cisy; Tl - Talysh; Tm - Tarim; Tr - obszar transkaukaski; Tu - Turan; UM - Umbria-Marche; WP - Pontides Zachodnie

Objaśnienia legendy: 1 - góry/wyżyny (aktywne tektonicznie); 2 - wyniesienia nieaktywne tektonicznie; 3 - niziny nieaktywne tektonicznie, bez osadów; 4-17 - środowiska sedymentacji [4 - lądowe nierozdzielne; 5 - rzeczne; 6 - rzeczno-jeziorne; 7 - jeziorne; 8 - eoliczne; 9 - przybrzeżne, przejściowe; 10 - paraliczne; 11 - międzypływowe; 12 - deltowe; 13 - płytkomorskie, szelfowe; 14 - skłonu kontynentalnego; 15 - głębokie oceany z sedymentacją (ze skorupą kontynentalną, przejściową lub oceaniczną); 16 - osady grawitacyjne (loby, spływy, turbidyty); 17 - głębokie oceany bez sedymentacji]; 18 - zlepieniec; 19 - piaskowiec, mułowiec; 20 -ił, łupek, mułowiec; 21 - biogeniczne osady krzemionkowe; 22 - wapień; 23 - dolomit; 24 - kreda; 25 - ewaporaty nierozdzielone; 26 - piasek i łupek; 27 - węglany i łupki; 28 - piaski i węglany; 29 - węglany i ewaporaty; 30 - utwory intruzyjne; 31 - utwory ekstruzyjne; 32 - centra spredingu oceanicznego i uskoki transformujące; 33 - nieaktywne grzbiety spredingu; 34 - aktywna subdukcja; 35 - uskok normalny; 36 - nasunięcie; 37 - uskok przesuwczy; 38 - dzisiejsza linia brzegu; 39 - wulkanizm ekstensyjny lub gorących plamek; 40 - wulkanizm subdukcyjny; 41 - wulkanizm nieokreślony; 42 - rafa; 43 - łupki bogate w substancję organiczną

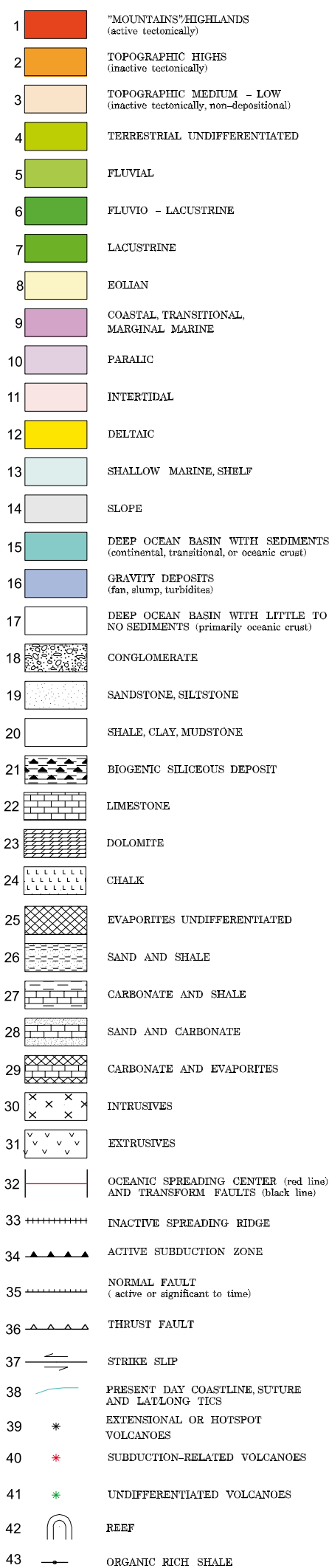

pes of Inner Carpathians and originated as deltaic and/or cliff-type transgressive marine deposits. They are Middle to Late Eocene in age;

- Huty Formation mainly contains more or less calcareous claystones with rare sandstones intercalations and occasionally of the Menilite-type shales in its bottom part. Conglomerates and very scarce and Mn-bearing carbonates occur locally;
- Zuberec Formation is characterized by typical mediumbedded flysch deposits of sandstones and claystones with rare intercalations of conglomerates; all of them originated from typical turbiditic currents on a deep-sea subsided basin floor;

- Biely Potok Formation consists of domination of thickbedded sandstones and rare, very thin intercalations of shales, 


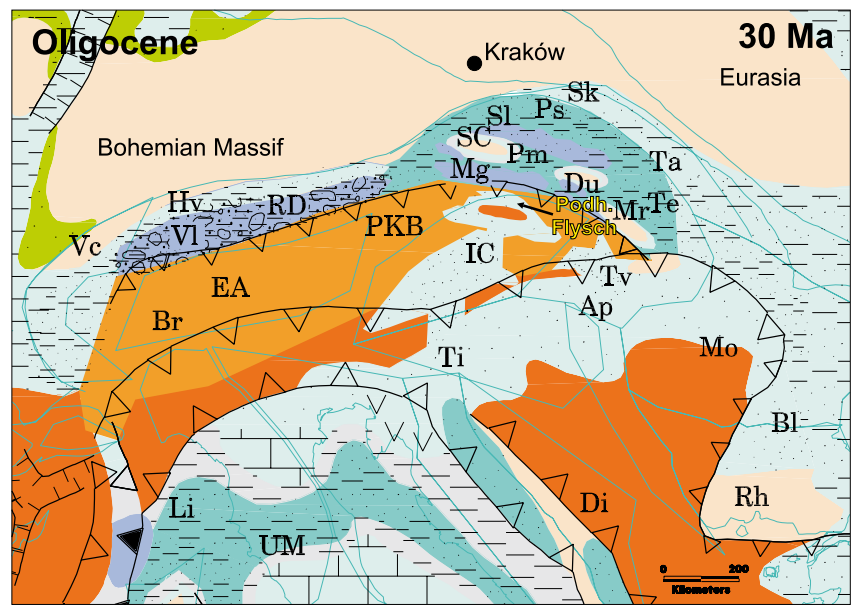

Fig. 8. Palaeogeography, palaeoenvironment and lithofacies of the circum-Carpathian area in Oligocene (plates' position about $30 \mathrm{Ma}$ ) (after Golonka et al., 2000, 2006b; slightly modified). Abbreviations: Ap - Apuseni Mts; Bl - Balkan Basin and fold belt; $\mathrm{Br}$ - Briançonnais terrane; Di - Dinarides; Du - Dukla Basin; EA - Eastern Alps; Hv - Helvetic shelf; IC - Inner Carpathians; Mg - Magura Basin; Mo - Moesia plate; Mr-Marmarosh Massif; Podh. Flysch - Podhale Flysch Basin; PKB - Pieniny Klippen Belt; Pm - Fore-Magura Basin; Ps - Subsilesian Ridge and slope zone; RD - Rhenodanubian Basin; Rh - Rhodopes; SC - Silesian Ridge (Cordillera); Sl - Silesian Basin; Sk - Skole Basin; Ta - Tarçau Basin; Ti - Tisza plate; Te - Teleajen Basin; Tv - Transylvanian Basin; UM - Umbria-Marche; Vc - Vercors zone; V1 - Valais trough. For other symbols and colors - see Fig. 7

Paleogeografia, paleośrodowisko i litofacje obszaru wokółkarpackiego w oligocenie (pozycja płyt litosfery około $30 \mathrm{mln}$ lat temu) (wg Golonka et al., 2000, 2006b; nieco zmienione). Objaśnienia: Ap - góry Apuseni; Bl - basen bałkański i pas fałdowań; Br - grzbiet briansoński; Di - Dynarydy; Du - basen dukielski; EA - Alpy wschodnie; Hv - szelf helwecki; IC - Karpaty Wewnętrzne; Mg - basen magurski; Mo - płyta mezyjska; Mr - masyw marmaroski; Podh. Flysch - basen fliszu podhalańskiego; PKB - pieniński pas skałkowy; Pm - basen przedmagurski; Ps - grzbiet podśląski strefa skłonu; $\mathrm{RD}$ - basen renodunajski; $\mathrm{Rh}$ - Rodopy; $\mathrm{SC}$ - grzbiet (kordyliera) śląska; $\mathrm{Sl}$ - basen śląski; $\mathrm{Sk}$ - basen skolski; Ta - basen Tarçau; Ti - płyta Cisy; Te - basen Teleajen; Tv - basen transylwański; UM - Umbria-Marche; Vc - strefa Vercors; V1 - rów Valais. Objaśnienia szrafur i kolorów - patrz Fig. 7

and sporadically conglomerates. The thickness of this formation is high variable, from some metres even up to few thousand metres;

- Pucov Formation is dominated by conglomerate wedges which occur in various stratigraphical positions of mentioned above formations.

In the Polish part of the Carpathian Palaeogene has been divided the following informal lithostratigraphical units, which correspond to mentioned above Slovakian units (comp. Gedl, 1999a, 2000a) (Fig. 5):

1. "Tatra Eocene" - it is equivalent of the Borove Formation;

2. Szaflary beds - hasn't good equivalent in Slovakian Palaeogene, but Soták \& Janočko (2001) and Soták et al. (2001) suggested correlating them to Šambron Beds (eastern part of the Central Carpathian Palaeogene Basin - to E from Vyšné Ružbachy). Szaflary beds are developed only in northernmost part of the Podhale Flysch, close to the Pieniny Klippen Belt, and therefore usually are strongly folded up to vertical position (Fig. 9A-C). Thin-bedded sandstones of the Szaflary beds consists normal flysch-type sedimentary structures such as: groove casts (Fig. 9D) moulds of scales arranged in flowparallel rows and longitudinal ridges (Fig. 9E, F);

3. Zakopane beds - it is equivalent of the Huty Formation, dominated by dark grey shales and thin layers of sandstones (sometimes with synsedimentary slump structures of submarine mass movements - Fig. 10A) and convolution (Fig. 10B), relatively rich in thin intercalations of tuffites (Fig. 10D, E). In this unit are well visible joints (Fig. 10C) which indicate tectonic stress plane;

4. Chocholów beds very well correspond to the Zuberec Formation with full spectrum of sedimentological (i.a., flutcasts, parallel(tractional)-lamination in sandstone) (Fig. 11AD) and palaeontological (carbonized piece of wood and/or trace fossils) (Fig. 11E-G) features, typical for turbiditic systems;

5. Ostrysz beds - it is equivalent of the Biely Potok Formation, the youngest unit of the Polish Palaeogene Flysch deposits, and occur locally in westernmost part of the Podhale region (Fig. 5).

According to biostratigraphical data all flysch-type units are Oligocene in age (Gedl, 2000a).

\section{Podhale Flysch as potential "geological school" and geotouristic unique region}

Several branches of geological sciences could be study in Podhale Flysch region, both by Carpathians geologists and, on the opposite side, by normal people, especially those which are interested in natural history of our Earth. This region has high educational potential for different generations and may be used as natural laboratory of several geological processes both ancient and present [according to one of the best adages of geological sciences - "present is a key to past", so-called uniformitarianism (actualism in geology), but sometimes vice versa "past is a key to present"]. Below you can find short enumeration of fundamental parts of geological sciences, especially those, which have been used in Podhale realm.

Sedimentological features of the Podhale Palaeogene are typical for submarine turbiditic processes which produced fan-shape lobes and/or aprons (Krawczyk, 1980; Westfalewicz-Mogilska, 1986; Marschalko, 1987; Wieczorek, 1989; Soták \& Janočko, 2001; Soták et al., 2001 with literature cited therein) and very well correspond to classical "flysch" literature (e.g., Mutti \& Ricci Lucchi, 1975; Shanmugam, 2000). Some sedimentological problems are the objects of hot disscusions and controversion (see - Gross \& Köhler, 1993; Wieczorek, 1989, 1995).

Palaeogene of the Podhale Flysch have also been intensively investigated in numerous other studies.

\section{Biostratigraphy}

This type of investigation have long history, since thirties-fifties years of last century up to recent, and were based 

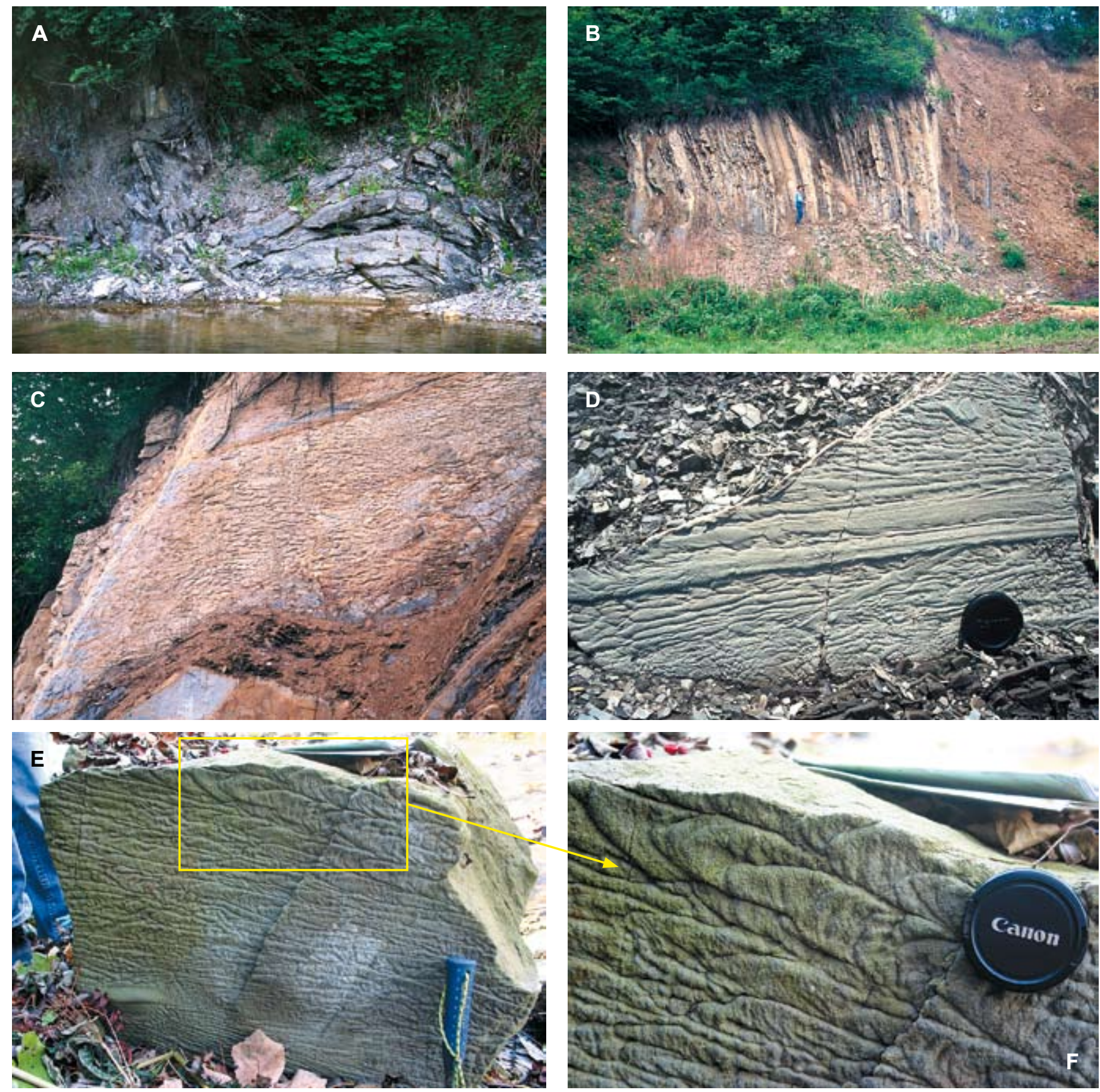

Fig. 9. Strongly folded Szaflary beds (A) or in vertical position (B) in contact zone with Pieniny Klippen Belt (Niedzica and Slovakia respectively) with conglomerates/coarse grained sandstones on the sole surface of beds (C) and perfect preserve mechanical hieroglyphs: groove casts (D) and moulds of scales arranged in flow-parallel rows and longitudinal ridges (E, F) (comp. Dżułyński, 1996, 2001) (D-F: D - Słowacja; E, F - Leśnica stream) • Silnie sfałdowane warstwy szaflarskie (A) lub w pozycji pionowej (B) w strefie kontaktu z pienińskim pasem skałkowym (odpowiednio - Niedzica i Słowacja) ze zlepieńcami/gruboziarnistymi piaskowcami na spągu ławic (C) i doskonale zachowanymi hieroglifami mechanicznymi: ślady wleczenia (D) i odlewy rzędowo ułożonych struktur łuskowych i podłużnych grzbietów (E, F) (por. Dżułyński, 1996, 2001) (D-F: D - Słowacja; E, F - potok Leśnica)

on different type of microfossils [foraminifers (both nummulitic and planktonic forms), calcareous nannoplankton, and dinocysts] (Dudziak, 1993; Olszewska \& Wieczorek, 1998; Gedl, 1999a, 2000). Correlation between different biostratigraphical schemes was recently done by Gedl (2000) who suggested Oligocene age for all flysch units. However, Garecka (2005) on the basis of calcareous nannoplankton, proposed for youngest Ostrysz beds earliest Miocene age.

\section{Petrography and mineralogy (including analysis of tuffitic layers)}

These primary researches were objects of interest several generations of geologists. The first focus was directed into the petrographical character of flysch rocks, their mineral composition and fraction, and distribution main and accessory minerals (e.g. Roniewicz \& Westfalewicz-Mogilska, 1974 and references cited therein). More intensive have been studied exotic-bearing deposits and exotics from them, both 

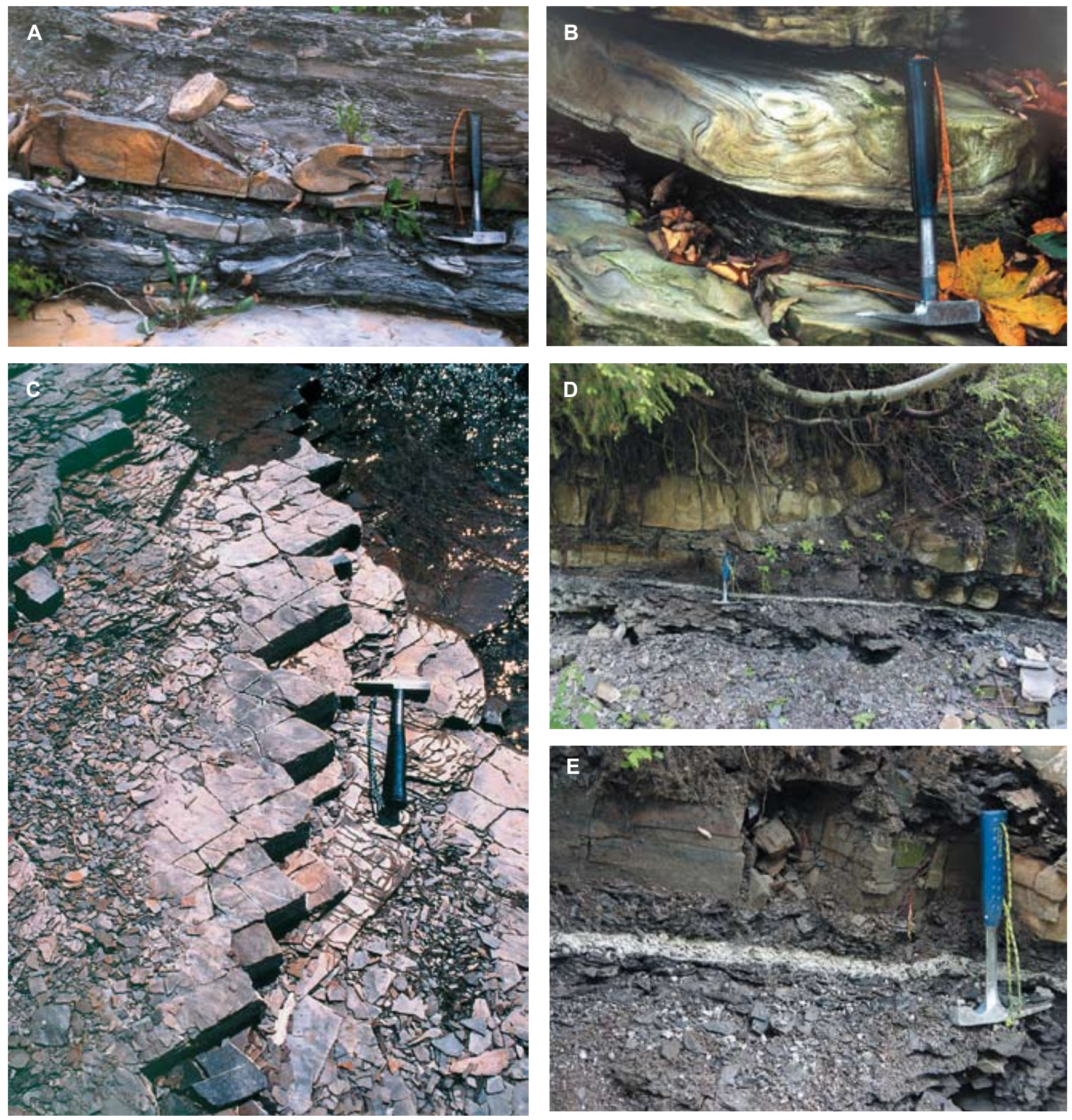

Fig. 10. Thin-bedded Zakopane Beds with slump structures (A) and convolutions (B) and good visible joints (C) (Murzasichle village), as well as thin tuffitic intercalations in grey shales (D, E) (Małe Ciche) - Drobnorytmiczny flisz warstw zakopiańskich ze strukturami spływowymi osuwisk podmorskich (A) i konwolucjami (B) oraz z dobrze widocznym ciosem (C) (Murzasichle) oraz cienkimi wkładkami tufitów w szarych łupkach (D, E) (Małe Ciche)

Fig. 11. Sedimentological and palaeontological features of the Chochołów beds (Zuberec Formation): A - conglomerates with large pebbles of the base of thick bed with gradational fractionation (Słodyczków stream); B - large flut casts on the base surface of finegrained sandstone bed (Słodyczków stream); C - big shale clasts in lowermost part of fine-grained sandstone bed (Słodyczków stream); D - parallel(tractional)-lamination in sandstone (Habovka; Slovakia); E - large piece of wood (carbonized) (Słodyczków stream); F, G - trace fossils (Taphrhelminthopsis - T and Paleodictyon - P) on the base of thin-bedded sandstone (Slovakia) - Sedymentologiczne i paleontologiczne walory warstw chochołowskich (formacja zuberecka): A - zlepieńce z dużymi otoczakami, w spągu grubej ławicy uziarnionej frakcjonalnie (potok Słodyczków); B - duże jamki wirowe na spągowej powierzchni drobnoziarnistego piaskowca (potok Słodyczków); C - duże klasty ilaste w przyspągowej części drobnoziarnistego piaskowca (potok Słodyczków); D - piaskowiec laminowany równolegle (Habovka; Slovakia); E - duży fragment uwęglonego kawałka drzewa (potok Słodyczków); F, G - skamieniałości śladowe (Taphrhelminthopsis - T and Paleodictyon - P) na spągowej powierzchni cienkoławicowego piaskowca (Słowacja) 

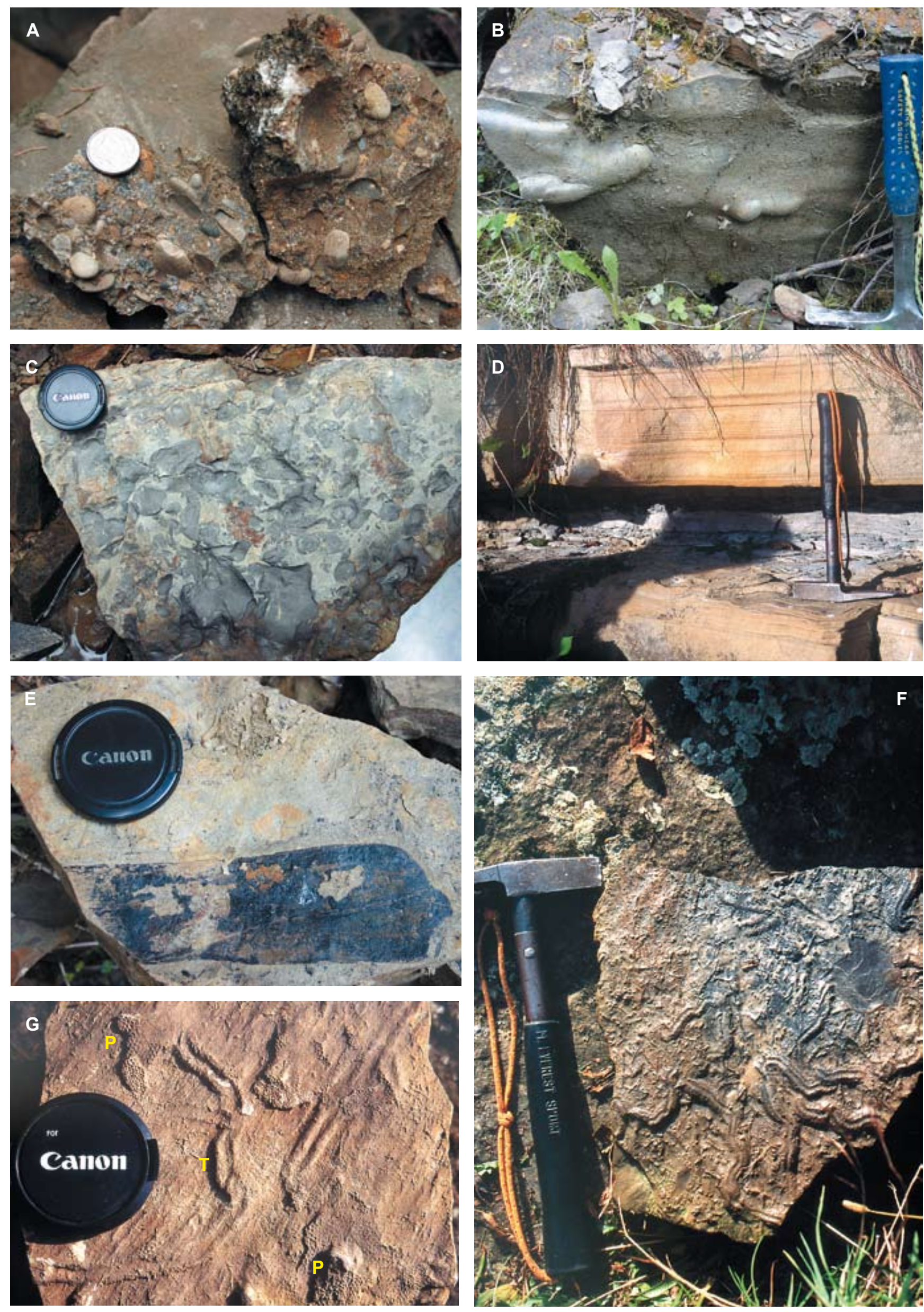
crystalline rocks and sedimentary one, mainly carbonates (Chowaniec \& Golonka, 1980; Burtan et al., 1984). More recently investigations of tuffitic rocks have been concentrated on their mineral character and geochemical meaning. About 30 tuffitic horizons have been recognized in the Oligocene Podhale flysch deposits, which indicate intensive volcanic activity within Carpathian region (Michalik \& Wieser, 1959). But the source area of such piroclastic material is still enigmatic and maybe connected with Inner Carpathian volcanism which originated by activity of subduction processes during geodynamic events in this part of AlpineCarpathian orogenic system. From the geotouristic point of view it is one of the most interesting features of the Podhale Flysch sequence and might help us to imagine about volcanoes and their role in evolution of Carpathian basins and then orogenic arc. More practice things, in geological field works, were possibilities to use them as good correlation markers, especially in such monotonous flysch sequence.

\section{Structural geology}

This part of geological knowledge is based on measurements of faults, folds, and/or joints and their statistical preparation to precise recognition of tectonic stress, especially during formation of tectonic wedges, accretionary prisms and formation of nappes. After that the reorientation of orogenic system (arc) and some rotation of isolated parts of mountains are most important to understand the movement events in post-orogenic tectonic activities. On the end of such investigations are so-called neotectonic researches, which based on very young (in geological sense of course) tectonic processes (e.g., Mastella, 1975).

\section{Organic geochemistry}

Oil and gas are necessary for all populations on the world. Therefore the applied geology is focus on discover of such type of rocks which accumulated these source material. Flysch-type rocks form good reservoirs for such accumulation by their porosity (especially coarse-grained sandstones surrounding by impermeable shales/claystones). First step in oil production is necessary to deposit rock rich in high organic matter. Origin of such organic-rich type of rocks depends on several events for example, as follow: biologic productivity (nutrient concentrating processes and settings usually connected with upwelling currents), depositional preservation of organic material in depositional systems, active subsiding depocentre at time of deposition, non-dilution of sedimented organic matter (low sedimentation rate), proximity to orogenic belts during interval of source rock deposition, drainage conduits into depocentre from uplifted areas, rate influence by climatic belts (e.g., wet zones) etc. etc. Unfortunately (may be good from environmental protection point of view), the Central Carpathian Palaeogene Flysch (including Podhale Flysch) not belongs to high potential source of oil area, in spite of the region is well recognized for accumulation of such type of energy. The basin-fill sequence has poor (TOC - Total Organic Carbon $-\leq 0.5 \%$ ) to fair (TOC $<1.0 \%$ ) quality of source rocks (e.g., Soták et al., 2001 with literature cited therein).

\section{Palaeontology and palaeoecology}

One of the most important rules in geology is - "no geology without palaeontology". This primary branch of geological sciences is necessary to recognize the age of the rocks, character of depositional systems, reconstruction of several sedimentological and palaeoenvironmental regimes, correlation potential of different facies by means of orthostratigraphic fossils and so on. In our case, in the Podhale Flysch we can see useful palaeontological data record, enabling step by step a detail reconstruction of origin and evolution of Podhale Basin as only small part of the whole Central Carpathians Palaeogene basins system. We can mainly use, as mentioned earlier, microfossils to determine palaeoenvironmental regimes in sedimentary basins as follow: bathymetry, palaeosalinity, bottom conditions, oxygen content both on the sea-floor and in water column, palaeocurrents, palaeoclimate, sedimentation rate, quantity and quality of nutrients etc. (e. g., Roniewicz \& Pieńkowski, 1977; Pieńkowski \& Westfalewicz-Mogilska, 1986; Gedl, 1999, 2000).

\section{Palaeogeography and basin analysis}

Palaeogeographical reconstruction and facies context of the Palaeogene flysch deposits originated in the Central Carpathian Palaeogene Basin is strictly connected with geodynamic regimes of formation of the Alpine-Carpathians arc in the light of Eurasian and Africa movements and collisions of smaller terranes (i.a., Marschalko, 1987; Tari et al., 1993; Golonka, 2004; Golonka et al., 2000, 2006a; Soták \& Janočko, 2001; Soták et al., 2001 with references cited therein) (Figs 6-8). In local, regional perspective development of the Podhale Flysch Basin and its filling by thick flysch sequence have been connected with strong subsidence tendency (especially during sedimentation of fine- and/or coarse-grained sandstones of Szaflary, Chochołów and Ostrysz beds). This subsidence was close correlate with strong erosion of uplifted source areas, which produced very large bulk of fresh sediments, which have been moved by turbiditic currents, debris flows and other gravitational mass movements down to deep basin floor, and produced lobes and turbiditic fans interrupted by catastrophic sedimentation of chaotic conglomerates (e.g., Pucov

Fig. 12. Geological position of Miocene andesites of the so-called Pieniny Andesite Line: A - geological sketch of the Pieniny Klippen Belt (Polish sector) and surrounding regions (after Birkenmajer, 1979; simplified) with location of Wżar Mt; B - main entrance to abandoned quarry; $\mathrm{C}$ - andesites with piroxenes and amphibolites; D - thermally change of flysch deposits of the Magura Unit (Outer Flysch Carpathians) on the contact with andesites; E- general view of Inner Carpathians from topmost part of the Wżar Mt • Pozycja geologiczna mioceńskich andezytów tzw. pienińskiej linii andezytowej: A - szkic geologiczny polskiej części pienińskiego pasa skałkowego z regionami otaczającymi i lokalizacją góry Wżar (wg Birkenmajer, 1979; uproszczone); B - główne wejście do nieczynnego kamieniołomu; C - andezyt z piroksenami i amfibolami; D - zmiany termiczne utworów fliszowych jednostki magurskiej (Zewnętrzne Karpaty fliszowe) na kontakcie z andezytami; E - widok ogólny na Karpaty Wewnętrzne ze szczytu Góry Wżar 

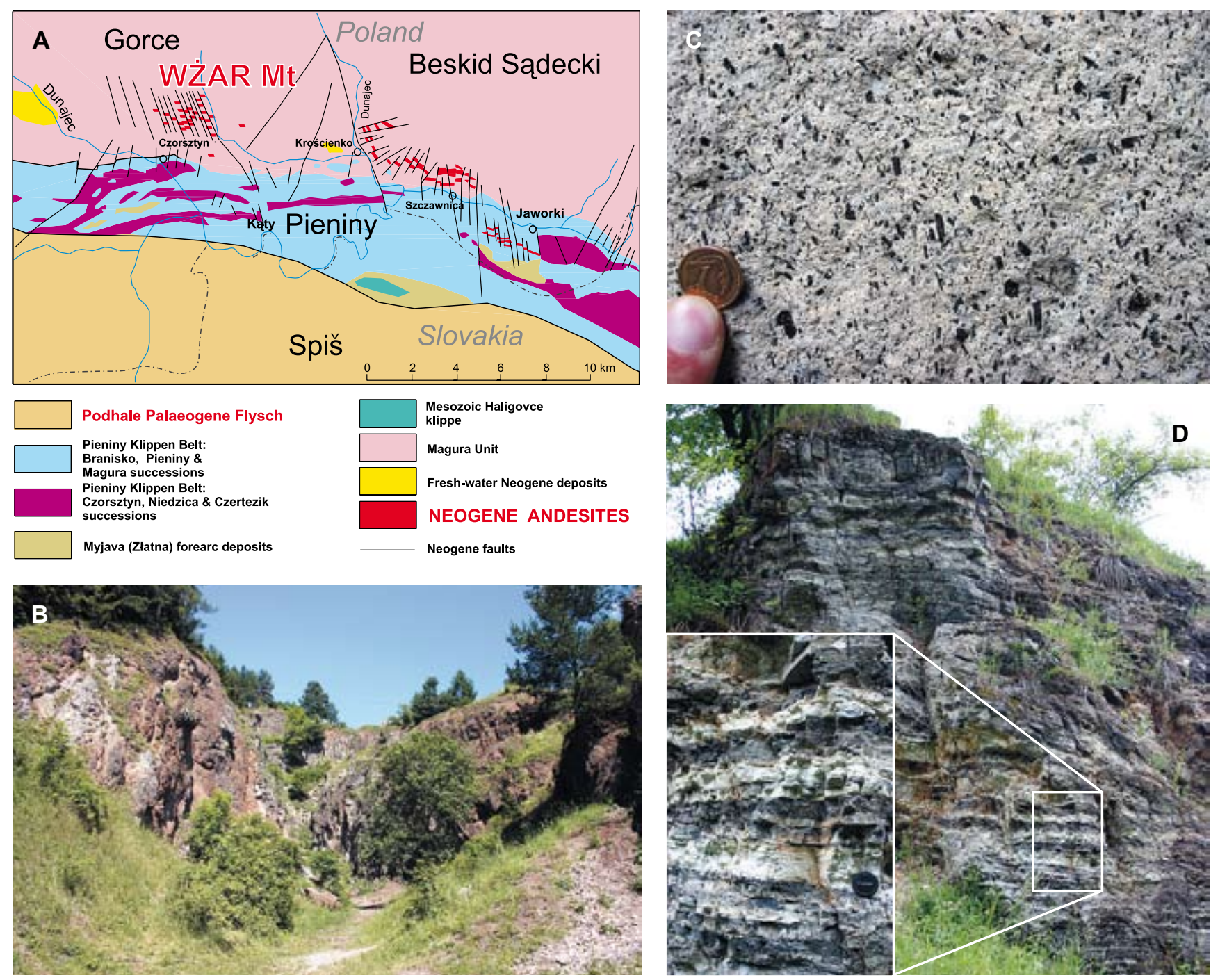

E

\section{TATRA MOUNTAINS}

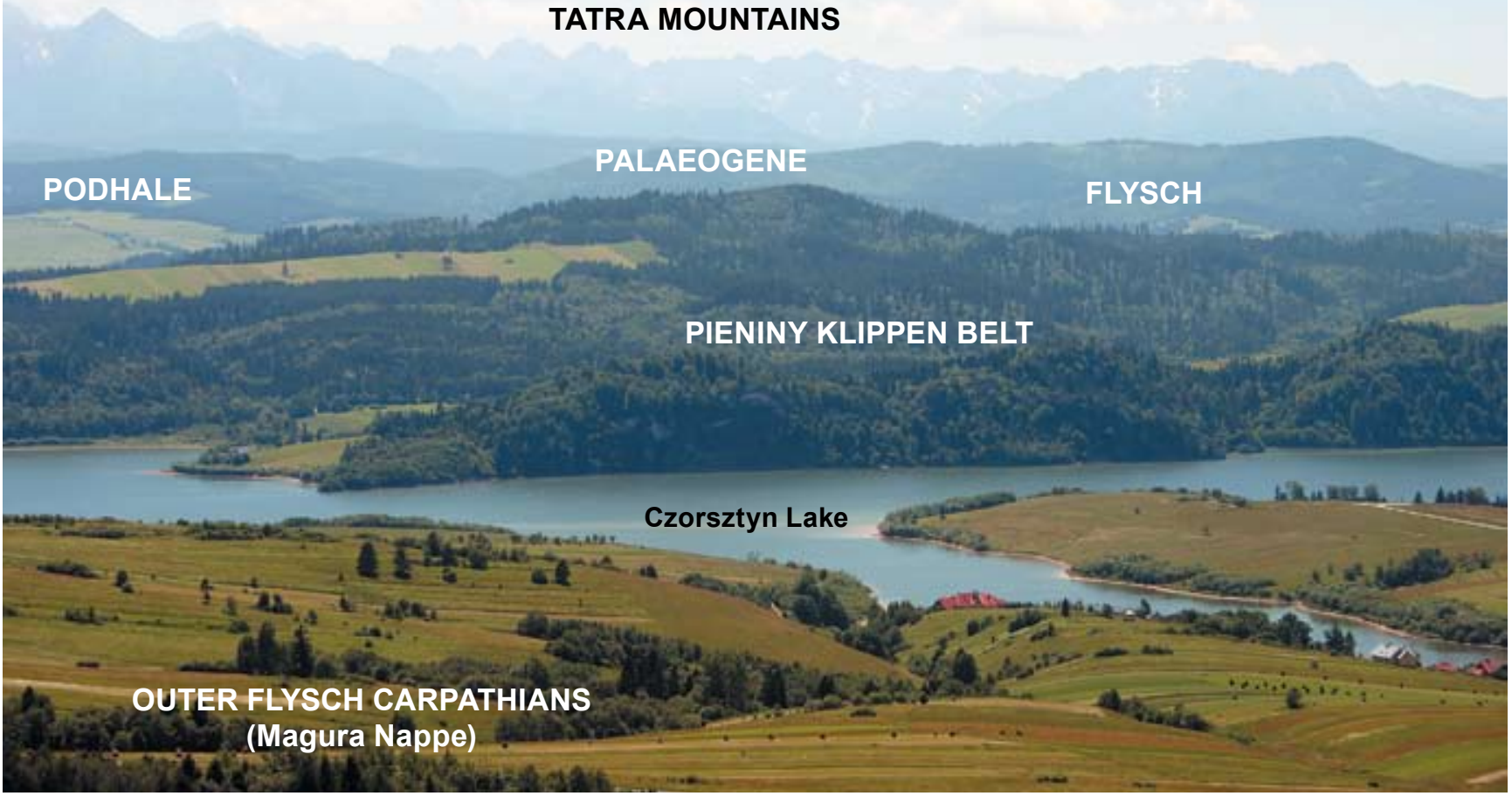


Formation) (Radomski, 1958; Marschalko, 1987; Westfalewicz-Mogilska, 1986; Wieczorek, 1989; Soták \& Janočko, 2001 with literature therein). Reconstruction of location of source areas is one of the most interesting problems in such flysch filling region and is mainly based on orientation of palaeocurrents interpreted by measurements of mechanical hieroglyphs (mainly flutcasts, groove casts, flow-parallel rows and longitudinal ridges etc.) (Figs 9D-F, 11B). According to such investigation, during the Late Oligocene the Central Carpathian Palaeogene Basin was filled up by sand-rich fans, for example. In Podhale region the flysch sequences form large elongate fan with generalized direction of sediment dispersal based on palaeocurrent orientation and proceeding from $\mathrm{W}$ and SW to E and NE (based on data from Radomski, 1958; partly Westfalewicz-Mogilska, 1986) (but earlier, during the Early Oligocene time, northern source area has been active - see Gedl, 2000). Such palaeocurrent system exhibit a downfan distribution of submarine fan facies indicated by directions of hieroglyphs, distribution of facies zones and evolution of facies tracts. Youngest deposits known recently from Podhale region are Upper Oligocene Ostrysz beds (Gedl, 2000) (after Garecka, 2005 - even up to lowermost Miocene), but most probably sedimentation in this basin continued later (during Early-Middle? Miocene times), but younger deposits are limited today (Cieszkowski, 1995). In fact, we don't know when precisely the sedimentation has finished \{?Middle Miocene [Middle Sarmatian (=Serravalian)]?\} (Cieszkowski, 1995). The burial, thermal history of this region is recorded in change of clay minerals (identification of maximum palaeotemperatures by measuring the ratio of smectite to illite in mixed-layer clay minerals separated from shales) and indicates deep burial episode just after sedimentation of Ostrysz beds (Late Oligocene) (Środoń et al., 2006; Środoń, 2007). On the other hand, the orogenic uplift and exhumation effects and moving up of the Podhale Flysch region could be measured by so-called apatite fission track analyses. This study indicates that uplift rates were rather slow and variable during Miocene time and not to exceed $0.4 \mathrm{~mm} /$ year (Anczkiewicz et al., 2005; Środoń et al., 2005). Based on such results, the calculations about the erosion and removal of huge thickness of enigmatic deposits [even more than $7 \mathrm{~km}$ ! (between 5.5 and $6.9 \mathrm{~km}$ in eastern part of the Podhale Basin) - twice bigger than general thickness known today] younger than Late Oligocene (earliest Miocene) (Środoń et al., 2005, 2006; Środoń, 2007) are surprisingly and high controversial (comp. Poprawa \& Marynowski, 2005). These authors suggested that calculated apparent thickness of removed deposits is significantly overestimated with compare to any realistic range of its value. On the other hand, Hurai and his co-authors (2006), using the fluid inclusions for recalculation of thermal and pressure history of burial process, suggested also similar value for fore-arc Podhale basin (5.4-6.6 km eroded rock column). For Outer Flysch Carpathians (Dukla Unit), as typical accretionary wedge, they proposed even about $11 \mathrm{~km}$ of rocks removed from recent erosion surface.

\section{Geophysical investigations}

Geophysical studies in Carpathians were focuses mainly on the Outer Flysch Carpathians and only few surveys con- centrated on the Podhale Flysch region. Deep soundings of magnetotelluric survey describe the deep-rooted lithospheric blocks and give general view of deep basement of Carpathians (Czerwiński et al., 2003; Golonka et al., 2005a). Another geophysical works are concentrated on palaeomagnetic researches, which for example can explain post-orogenic rotation of regions and/or their parts. In Podhale case, results of such investigations indicate counterclockwise movements of the Podhale block along the peri-Pieniny strike-slip faults (Márton et al., 1999).

\section{Geothermal energy}

This type of "clean energy" is very useful for normal life (including tourism and recreation) for people of all generations, and that's why the Podhale region is more and more attractive for many tourists. In some boreholes the terrestrial heat flow values have been determined at $55.6 \mathrm{~mW} / \mathrm{m}^{2}$ and $60.2 \mathrm{~mW} / \mathrm{m}^{2}$ (Zakopane IG-1 and Bańska IG-1 wells respectively - see Fig. 3B) (Chowaniec \& Kępińska, 2003). The temperatures at depths of $2-3 \mathrm{~km}$ amount to over $80-90^{\circ} \mathrm{C}$, which is markedly higher than those resulting from the normal geothermal gradient (between 1.9 and $2.3^{\circ} \mathrm{C}$ per $100 \mathrm{~m}$ ). Chowaniec \& Kępińska (2003) suggest that increased upflow of heat and/or hotter fluids from the deeper part of the system occur along discontinuity planes. Very sharp contact of the Podhale Flysch zone with the Pieniny Klippen Belt at northern side is presumable a key to understanding such phenomena. The thermal anomalies recorded on the tectonic contact between the Podhale Flysch Basin and the Pieniny Klippen Belt is about $2-3^{\circ} \mathrm{C}$ higher than average background values. The main collectors of geothermal water is both nummulitic Palaeogene and Mesozoic basement mainly built by Triassic sedimentary rocks and belong to different tectonic Tatric units (Wieczorek \& Barbacki, 1997; Chowaniec \& Kępińska, 2003).

\section{Quaternary geology (including Late Neogene) and geomorphology}

The youngest history of the Podhale Basin has very wide scientific literature (e.g., Klimaszewski, 1952; Zuchiewicz, 1998; see also - Zuchiewicz: http://www.uj.edu.pl/ING/neotectonics/nk.pdf) which concern both the Neogene Orava Basin (Baumgart-Kotarba, 2001; Baumgart-Kotarba et al., 2001) (Figs 4, 5) filled mainly by freshwater clastic deposits, and central part of Podhale (Birkenmajer, 1978). Palaeoclimatic reconstruction of this region are based on palynological studies (in Pliocene time) and malacological one (Holocene - Alexandrowicz W.P., 1997). The malacological assemblages are mainly connected with calcareous tufa (Alexandrowicz, W.P., 1997) and therefore, this Late Glacial and Holocene deposits and travertines are most important to documentation of the youngest geological history of the Podhale region, changes of climate and palaeoenvironments. Some molluscan assemblages (mainly land gastropods) which abundantly occur in such type of deposits are very useful for documentation of continuous changes during the last 11000 years (Alexandrowicz, W.P., 1997). On the other hand, a lot of localities of peatbogs in the Orava-Nowy Targ area can help to understand some Quaternary vegetation/climate his- 
tory of this region. Usually, the thickness of these peatbogs ranges 1.1-7.1 metres, and in this area occur 26 peatbogs. Another investigations of such young (in geological sense of course) period, up to recent, are based on neotectonic movements in Podhale (Zuchiewicz, 1998), aerial photographs interpretation and landform analysis (Ozimkowski, 1991) and also interpretations of landslides (Mastella, 1976). Podhale is also a region of earthquakes reaching the magnitude 5.1 in the Richter scale and causing damages in the nearby villages (Chrustek \& Golonka, 2005). These earthquakes are related to the modern fault's activity.

\section{Nature protection (geological heritage)}

In the Podhale region only 2 localities are formally protected by Polish law as nature monuments: spherosiderites from Zakopane beds in Chłabowski stream near Zakopane and waterfall (7 $\mathrm{m}$ high) formed on horizontal layers of Zakopane beds in Kacwin village (eastern Podhale) (Chowaniec \& Golonka, 1981; Alexandrowicz, Z., 2000). Six additional outcrops are planed to protect as documentary sites of inanimate nature: Dzianisz (synsedimentary slump structures), Bustryk (the same as above), Stasikówka (perfect outcrop of flysch sequence), Kotelnica near Zakopane (slump structures), Karpenciny (same as above) and Gliczarów (calcareous tufa) (Alexandrowicz, Z., 2000). Several others geological and geomorphological outcrops/landforms in the Podhale Flysch need to protection in law as good both educational and scientific objects.

\section{Geotourism}

Last, but not least, part of geological science activity is new branch of geology, concentrated on education and popularization of modern geological knowledge, based on promotion of spectacular objects of inanimate nature. All mentioned above, more or less scientific, geological problems are potential very well to propagation of Earth sciences. On relatively no large area we can found here a lot of interesting geological objects which covered whole long history of the Podhale Flysch region. As we tried to it's explain from global scale (Fig. 6) trough regional one (Eurasiatic) (Fig. 7) up to local (Figs 8-11), the Podhale Palaeogene Flysch is our beautiful "small village" which we have both understand and protect. Some of them were mentioned above as perfect objects to study of geology and as geological heritage for future generations.

\section{Wżar Mountain}

Finally, we want to invite you to visit of Wżar Mt (especially during good sunny day) where looking southward, we can see perfect panorama of Tatra Mountains, Pieniny and Podhale trough with Czorsztyn Lake (Fig. 12), and looking northward of Gorce Mountains are visible (see Golonka et $a l ., 2005 \mathrm{~b}$ ). You can visit also abandoned quarry of Miocene andesites which belong to the so-called Pieniny Andesite Line (Birkenmajer, 1986). The Neogene volcanic activity in Carpathian-Pannonian region was widespread. Today in this region the Neogene andesites, both in the Pieniny Mts and in flysch rocks of the Outer Flysch Carpathians, are relatively numerous but their volume is low. The Pieniny Andesite Line is an about $20 \mathrm{~km}$ long and $5 \mathrm{~km}$ wide zone, which cut both Mesozoic-Palaeogene rocks of the Pieniny Klippen Belt and Palaeogene flysch of the Magura Nappe of the Outer Flysch Carpathians. Andesites occur in the form of dykes and sills. At the Wżar Mt two generations of andesitic dykes occur. Numerous older dykes are sub-parallel to the longitudinal distribution of the Pieniny Klippen Belt structure and younger are perpendicular to the first and are represented only by three dykes (Birkenmajer, 1979; Birkenmajer \& Pécskay, 2000). Spatial distribution, temporal relationships, and geochemical evolution of magmas contribute to interpretation of the geodynamic development of this area (e.g., Birkenmajer, 1986; Kováč et al., 1998; Golonka et al., 2005a, b). According to Birkenmajer (2003) and Birkenmajer \& Pécskay (2000), andesitic rocks in the Pieniny region are products of hybridization of primary mantle-derived magma over subducted slab of the North European plate as effect of Sarmatian post-collisional volcanic arc. Detailed geochemical data suggested that parental magmas derived from a metasomatized subcontinental lithospheric mantle (Trua et al., 2006). Numerous petrographical varieties were distinguished, based mainly on the composition of phenocryst assemblages (Michalik et al., 2005). The mainly Sarmatian age of andesites is radiometrically (K-Ar) determined as within the range of 13.5 to $10.8 \mathrm{Ma}$ (Birkenmajer \& Pécskay, 2000; Trua et al., 2006). Close to entrance to old quarry both andesites and flysch rocks of the Magura nappe are altered near contacts. This thermal metamorphism changes both colour of these thin-bedded flysch and hardening of them (Fig. 12D). Wżar Mt is one of the geological objects classified for the entry into the European network of GEOSITES (Alexandrowicz, Z., 2006).

\section{Streszczenie}

\section{Paleogeński flisz podhalański jako atrakcyjny region geoturystyczny - pierwsze spojrzenie na jego unikalne walory geologiczne}

\section{Michal Krobicki \& Jan Golonka}

Region Podhala jest bardzo atrakcyjnym obszarem dla turystów, zarówno ze względu na bliskość Tatr z jednej strony jak i Pienin z drugiej. Taka jego geograficzna pozycja umożliwia łatwy dostęp do tych słynnych dwóch regionów, które są głównymi atrakcjami geoturystycznymi Polski południowej (Krobicki \& Golonka, 2008). Lecz obszar Podhala ze swoimi łagodnymi wzgórzami, dzikimi lasami, czystymi rzekami i strumieniami również oferuje spektakularne obiekty przyrody nieożywionej naszych Karpat poprzez możliwość zapoznania się z utworami paleogeńskiego fliszu. Możliwe, że pierwsza impresja ukazuje tylko monotonną serię skał typu fliszowego, lecz liczne jego cechy litologiczne i zjawiska tektoniczne niespodziewanie dają nam możliwość rozpoznania skomplikowanej historii powstania podhalańskiego fliszu paleogeńskiego. Głównym celem niniejszej pracy jest zwrócenie 
uwagi na ten fenomen geologiczny, a szczególnie litologiczne zróżnicowanie skał fliszowych, ich sedymentologicznych cech, aspektów jego stratygrafii i paleontologii w nawiązaniu do regionalnej pozycji Podhala i jego paleogeograficznej historii w szerszym kontekście geodynamicznym.

$\mathrm{Na}$ terenie Podhala utwory paleogenu są podzielone na dwie części. Starsza jest reprezentowana przez tzw. „eocen tatrzański" (środkowy-górny eocen) i zawiera zlepieńce (Passendorfer, 1983) i utwory skał wapiennych (np. wapienie numulitowe) (Roniewicz, 1969, 1979; Bac-Moszaszwili et al., 1979; Kulka, 1985; Bartholdy et al., 1999). Kompleks młodszy (wieku oligoceńskiego) jest reprezentowany natomiast przez utwory fliszowe (tzw. flisz podhalański). Sugerowana jest luka stratygraficzna pomiędzy „eocenem tatrzańskim” a przykrywającym go fliszem (Gedl, 2000). W nawiązaniu do Olszewskiej \& Wieczorka (1998) utwory paleogenu Podhala reprezentują cztery wyraźne facje: środkowoeoceńskie zlepieńce pochodzenia deltowo-klifowego (0-100 m miąższości), górnoeoceńskie, płytkomorskie (sublitoralne) wapienie numulitowe platformy węglanowej (max. 100-150 m), najwyższego eocenu margle hemipelagiczne z planktonicznymi otwornicami (ok. 20 m), i oligoceński flisz (2700-3400 m) typowej sedymentacji turbidytowej z sekwencją osadową charakteryzującą się zwiększaniem się ilości skał gruboziarnistych $\mathrm{w}$ górę profilu.

Flisz podhalański należy do większej jednostki, tzw. centralno-karpackiego basenu paleogeńskiego (Marschalko, 1987) (Fig. 1) (Soták \& Janočko, 2001; Soták et al., 2001; Golonka et al., 2005 z literaturą). Polska część tego basenu była wypełniana głównie przez wielkiej miąższości utwory fliszowe (zlepieńce, piaskowce, mułówce, iłowce) podmorskich turbidytowych stożków sedymentacyjnych (Westfalewicz-Mogilska, 1986; Marschalko, 1987; Wieczorek, 1989; Soták \& Janočko, 2001). Obecnie flisz podhalański znajduje się pomiędzy pienińskim pasem skałkowym na północy i Tatrami na południu (Fig. 2-5). Flisz podhalański zajmuje dzisiaj strukturalną depresję i ma kształt rozległej synkliny (Fig. 3, 5).

Rekonstrukcje paleogeograficzne sugerują pierwotną pozycję tego basenu oddaloną o setki kilometrów na południowy zachód od dzisiejszego miejsca jego występowania (Csontos et al., 1992). Podczas oligocenu miała miejsce tektoniczna kolizja Afryki i Eurazji (Fig. 6). Skutkiem tej kolizji była orogeneza alpejska, która doprowadziła do powstania wielkiego łuku górskiego alpejsko-karpacko-dynarydzkiego (Golonka, 2004) (Fig. 6-8). Równocześnie powstały zapadliska przed- i śródgórskie, które wypełniane były utworami molasy, pochodzącymi z erozji świeżo spiętrzonych gór i przetransportowanymi do okalających je mórz (tzw. Paratetyda). Uformowane płaszczowiny przesuwały się w kierunku na północ (północny-wschód) i formowały tzw. pryzmę akrecyjną (dzisiejsze Karpaty fliszowe) (Fig. 1-3) u czoła której formowały się wspomniane zapadliska przedgórskie (Kováč et al., 1998; Ślączka, 1996). Płaszczowiny te zostały oderwane od swojego macierzystego podłoża i nasunięte na utwory przedpola (platforma wschodnioeuropejska) zbudowanego ze skał paleozoicznych i mezozoicznych południowej Polski (Fig. 1-3). Proces ten zakończył sie w późnym miocenie (Oszczypko, 1999; Golonka et al., 2004, 2006b).
Rejon Podhala jest północną częścią tzw. paleogeńskiego basenu centralno-karpackiego, do którego m. in. należą po stronie słowackiej baseny: Liptowa, Orawy czy Spisza. W miejscach tych, jak i na terenie Podhala, utwory paleogenu leżą niezgodnie na mezozoicznych płaszczowinach tatrzańskich (Fig. 3), co zostało udowodnione licznymi wierceniami. $Z$ drugiej strony jest powszechnie akceptowany pogląd, że w paleogenie Tatry w całości były przykryte osadami fliszowymi, usuniętymi później przez erozję w trakcie podnoszenia się bloku tatrzańskiego. Tuż po ruchach fałdowych i powstawaniu płaszczowin tatrzańskich w późnej kredzie, nastąpiła transgresja morska, która pozostawiła po sobie zlepieńce i wapienie numulitowe eocenu, na których dopiero osadziły się dużej miąższości utwory fliszowe (około 3000 - 3400 metrów), które przykryły i Tatry (Fig. 4, 5).

Paleogeograficzna pozycja paleogeńskiego basen podhalańskiego została przedstawiona na kolejnych mapach paleogeograficznych ukazujących na kolejnych zbliżeniach umiejscowienie tego basenu od skali globalnej poprzez europejskoazjatycką aż do skali paleogeografii basenów karpackich (Fig. 6-8) z zaznaczonym rozmieszczeniem głównych litofacji oligocenu (Golonka et al., 2005). Dzisiejsza pozycja fliszu podhalańskiego na kontakcie z pienińskim pasem skałkowym ukazuje silnie ztektonizowane warstwy wielu łusek typowego tektonicznego kontaktu dwóch wielkich jednostek geologicznych (Fig. 9A-C). Na dodatek, jak to wynika z badań paleomagnetycznych, wzdłuż tego kontaktu nastąpiła rotacja całego obszaru podhalańskiego wbrew ruchu wskazówek zegara wzdłuż głęboko zakorzenionego uskoku przesuwczego.

Na Słowackiej Orawie eoceńsko-oligoceńskie sekwencje osadowe zostały formalnie wyróżnione jako tzw. grupa podtatrzańska (Gross et al., 1984, 1993), która jest ekwiwalentem fliszu podhalańskiego. Odpowiednikiem eocenu tatrzańskiego jest tzw. formacja borowska (Borové Formation) o zmiennych facjach klastyczno-wapiennych - brekcji sedymentacyjnych, zlepieńców, piaskowców. Z kolei jakimś odpowiednikiem utworów warstw szaflarskich (najstarsze wydzielenie fliszowe na Podhalu) (Fig. 9) są utwory warstw szambrońskich, a kolejne wydzielenia litostratygraficzne sobie odpowiadające to: polskie warstwy zakopiańskie (Fig. 10) to słowacka formacja huciańska (Huty Formation) - zdominowane przez utwory drobnorytmicznego fliszu z przewagą mułowców i iłowców; warstwy chochołowskie (Fig. 11) odpowiadają formacji zubereckiej (Zuberec Fm.) - średnioi gruborytmiczny flisz proksymalny z przewagą piaskowców nad łupkami; i najmłodsze wydzielenie fliszu podhalańskiego - warstwy ostryskie (Fig. 5) to słowacka formacja białopotocka (Biely Potok Fm.) - gruboziarniste piaskowce i podrzędnie występujące iłowce.

Geoturystyczna promocja Podhala ma pełną możliwość realizacji poprzez ukazanie historii procesów geologicznych, które doprowadziły do obecnego wykształcenia utworów fliszowych na tym terenie. Ta wielowątkowa historia oparta jest na rezultatach bardzo zróżnicowanych badań geologicznych, a flisz podhalański może być ,geologiczną szkołą” na obszarze tego unikalnego regionu geoturystycznego.

Badania sedymentologiczne udokumentowały typowe cechy podmorskich stożków i/lub fartuchów procesów sedymentacji turbidytowych prądów zawiesinowych (Fig. 9D-F; 
10A, B; 11) (Krawczyk, 1980; Westfalewicz-Mogilska, 1986; Marschalko, 1987; Wieczorek, 1989; Soták \& Janočko, 2001; Soták et al., 2001).

Badania biostratygraficzne oparte są na kilku grupach, wyłącznie mikroskamieniałości (otwornice, nanoplankton wapienny, dinocysty) (Dudziak, 1993). Te ostatnie dały dobre podstawy do szczegółowego datowania fliszu podhalańskiego na oligocen (najmłodszy paleogen) (Gedl, 1999a, 2000).

Badania petrograficzno-mineralogiczne skupiały się na rozpoznaniu składu mineralnego piaskowców fliszowych z jednej strony (e.g. Roniewicz \& Westfalewicz-Mogilska, 1974) i rozpoznaniu litologii egzotyków zarówno skał krystalicznych jak i osadowych (głównie wapiennych) (Chowaniec \& Golonka, 1980) z drugiej. Natomiast badania cienkich wkładek tufitów (Fig. 10D, E), których zidentyfikowano w tym regionie około 30, koncentrowały się na dokładnym rozpoznaniu ich petrografii i geochemicznego składu w celu odtworzenia rodzaju wulkanizmu, z którym były związane (Michalik \& Wieser, 1959). Lecz do tej pory obszar gdzie mogły „dymić” wulkany produkujące takie utwory piroklastyczne pozostaje nadal bliżej nieznany, generalnie uznając, że były one zlokalizowane gdzieś na terenie ówczesnych Karpat Wewnętrznych. Z geoturystycznego punktu widzenia skały tego rodzaju są fantastycznym obiektem dydaktycznym uzmysławiającym obecność kopalnych wulkanów i ich roli w odtwarzaniu geologicznej historii obszaru.

Badania z geologii strukturalnej prowadzone były bardzo intensywnie na terenie Podhala (Mastella, 1975). Umożliwiły one wyznaczenie głównych kierunków naprężeń przy powstawaniu różnorodnych fałdów (Fig. 9A, B) czy ciosu, który bardzo efektownie zaznacza się zwłaszcza w obrębie cienkoławicowych piaskowców warstw zakopiańskich (Fig. 10 C).

Poszukiwania ropy i gazu nie dały pozytywnych rezultatów w tym rejonie ze względu na generalnie niską zawartość materii organicznej w utworach fliszu podhalańskiego (tzw. TOC - Total Organic Carbon $-\leq 0.5 \%$ ) (Soták et al., 2001), ale próby ich stwierdzenia były podejmowane.

Badania paleontologiczne i paleoekologiczne umożliwiły odtworzenie pierwotnych warunków środowiska morskiego i otaczających lądów (Fig. 11E) za pomocą analizy mikroskamieniałości czy tzw. skamieniałości śladowych będących kopalnym zapisem aktywności życiowej organizmów na dnie zbiornika sedymentacyjnego (Fig. 11F, G) (Roniewicz \& Pieńkowski, 1977; Pieńkowski \& Westfalewicz-Mogilska, 1986; Gedl, 1999, 2000).

Analiza basenów i paleogeografia dały podstawy do rekonstrukcji w czasie i przestrzeni położenia oligoceńskiego basenu fliszu podhalańskiego zarówno w kontekście innych basenów karpackich w tym czasie jak i geotektonicznych uwarunkowań w skali ponadregionalnej (Fig. 6-8). Rekonstrukcje takie są intensywnie prowadzone po słowackiej stronie, gdzie występuje szereg lokalnych (sub)basenów jako składowe centralno-karpackiego basenu paleogeńskiego (Marschalko, 1987; Soták \& Janočko, 2001; Soták et al., 2001 z literatura tam cytowaną). Co prawda wkład i polskich geologów jest w tej części znaczący (Radomski, 1958; Westfalewicz-Mogilska, 1986; Wieczorek, 1989), mimo że niektóre z ich propozycji wzbudziły pewne kontrowersje (Gross \& Köhler, 1993; Wieczorek, 1989, 1995).
Badania geofizyczne dotyczą głównie głębszego podłoża utworów fliszowych i prowadzone były na szerszą skalę regionalną, wykraczając poza ten region geologiczny (np. badania magnetotelluryczne) (Czerwiński et al., 2003; Golonka et al., 2005). Z drugiej strony analizy paleomagnetyczne dały możliwość oszacowania post-orogenicznych ruchów tektonicznych (rotacji) względem sąsiednich regionów (Márton et al., 1999).

Wykorzystanie energii geotermalnej jako „czystej energii" ma w wielu miejscach świata tendencję wzrostową. Obszar Podhala jest pod tym względem wyjątkowy i ze swoją synklinalną budową geologiczną, charakterem podłoża płaszczowin tatrzańskich i tektonicznym kontaktem od północy z pienińskim pasem skałkowym ukształtował dogodne warunki do generacji tych ciepłych wód (Chowaniec \& Kępińska, 2003). Niektóre z nich z powodzeniem są zagospodarowywane zarówno w celach gospodarczych jak i rekreacyjnych (kąpieliska).

Geologia czwartorzędu i geomorfologia dostarczają nam informacji o najmłodszym okresie $\mathrm{w}$ dziejach ziemi aż do współczesności, pozwalając zrozumieć tak niedawno (w skali czasu geologicznego oczywiście) toczące się procesy na tym obszarze. Historia basenu Orawsko-Nowotarskiego (mimo że sięgająca czasów neogenu) i później zapisane wydarzenia holoceńskie w wielu stanowiskach martwic wapiennych z liczną malakofauną, dają możliwość wglądu w zmiany klimatu w czwartorzędzie czy zmiany paleośrodowisk lądowej sedymentacji. Ruchy neotektoniczne ze swoją zmiennością tutaj zostały dobrze udokumentowane, wpływając na dzisiejszy obraz morfologiczny niecki podhalańskiej (Klimaszewski, 1952; Baumgart-Kotarba, 2001; Alexandrowicz W. P., 1997; Zuchiewicz, 1998).

Ochrona przyrody i ochrona dziedzictwa geologicznego sciśle wiąże się z geoturystyką. Sam fakt, że tylko 2 stanowiska geologiczne $\mathrm{z}$ rejonu fliszu podhalańskiego są formalnie chronione polskim prawem, świadczy dobitnie o zaniechaniach środowiska geologicznego w czynnej ochronie stanowisk i obiektów geologicznych tego obszaru (Chowaniec \& Golonka, 1981; Alexandrowicz, Z., 2000). W ostatnich latach wytypowano kolejnych 6 dodatkowych odsłonięć potencjalnie dogodnych do ochrony [Dzianisz - synsedymentacyjne osuwisko podmorskie), Bustryk (to samo), Stasikówka (doskonałe odsłonięcie sekwencji fliszu), Kotelnica koło Zakopanego (struktury spływów podmorskich), podobnie Karpenciny i Gliczarów (pełny profil martwicy wapiennej)] (Alexandrowicz, Z., 2000).

$\mathrm{Na}$ tle wymienionych powyżej działów geologii i nauk pokrewnych widać bardzo wyraźnie jak niewykorzystany potencjał geoturystyczny kryje w sobie obszar występowania fliszu podhalańskiego z cała swoją złożonością, ale i z dogodnością śledzenia procesów i zjawisk geologicznych. W tym sensie rejon ten idealnie nadaje się do promocji nauk geologicznych i może stanowić doskonały poligon do nauki podstawowych (ale i bardziej wyszukanych - patrz główny tekst anglojęzyczny) praw z życia naszej planety zachowanych dla nas w stanie kopalnym. Geoturystyka powinna otworzyć obszar Podhala przed turystami ciekawymi poznania otaczającego ich świata (fliszowego jego wycinka) i pragnącymi czynnie spędzać swój wolny czas. 
Autorzy pragną podziękować Beacie Kępińskiej i Józefowi Chowańcowi za pomoc w przygotowaniu figury $5 \mathrm{~A}$, Renacie Stadnik figury 5B, a Recenzentowi za cenne uwagi do tekstu. Niniejsza praca była finansowana w ramach badań statutowych AGH (um. nr 11.11.140.447)

\section{References (Literatura)}

Alexandrowicz, W.P., 1997. Malacofauna of Quaternary deposits and environmental changes of the Podhale Basin during the Late Vistulian and Holocene. Folia Quaternaria, 68 : 7-132. (In Polish, English summary)

Alexandrowicz, Z., 2000. Podhale and Pieniny Klippen Belt; Protected areas and objects. In: Alexandrowicz, Z. \& Poprawa, D. (Eds.): Geodiversity conservation of the Polish Carpathians (with map of protected and proposed for protection area and objects of inanimated nature): 29-40. Warszawa

Alexandrowicz, Z., 2006. Framework of European geosites in Poland. Nature Conservation, 62: 63-87.

Anczkiewicz, A.A., Zattin, M. \& Środon, J., 2005. Cenozoic uplift of the Tatras and Podhale basin from the perspective of the apatie fission track analyses. Mineralogical Society of Poland - Special Papers, 25: 261264.

Bac-Moszaszwili, M., Burchart, J., Głazem, J., Iwanow, A., Jaroszewski, W., Kotański, Z., Lefeld, J., Matella, L., Ozimkowski, W., Roniewicz, P., Skupiński, A. \& Westfalewicz-Mogilska, E., 1979. Geological map of the Polish Tatra Mountains 1:30 000. Wydawnictwa Geologiczne, Warszawa. (In Polish, English summary)

Bartholdy, J., Bellas, S.M., Ćosović, V, Fuček, P. \& Keupp, H., 1999. Processes controlling Eocene mid-latitude larger foraminifera accumulations: modelling of the stratigraphic architecture of a fore-arc basin (Podhale Basin, Poland). Geologica Carpathica, 50, 6: 435-448.

Baumgart-Kotarba, M., 2001. Continuous tectonic evolution of the Orava Basin (Northern Carpathians) from Late Badenian to the present-day? Geologica Carpathica, 52: 103-110.

Birkenmajer, K., 1978. Neogene to Early Pleistocene subsidence close to the Pieniny Klippen Belt, Polish Carpathians. Studia Geomorphologica Carpatho-Balcanica 12: 17-28.

Birkenmajer, K., 1979. Przewodnik geologiczny po pienińskim pasie skałkowym. Wydawnictwa Geologiczne, 1-237, Warszawa. (In Polish only)

Birkenmajer, K., 1986. Stages of structural evolution of the Pieniny Klippen Belt, Carpathians. Studia Geologica Polonica, 88: 7-32.

Birkenmajer, 2003. Post-collisional Late Middle Miocene (Sarmatian) Pieniny Volcanic Arc, Western Carpathians. Bulletin of the Polish Academy of Sciences, Earth Sciences, 51, 1: 79-89.

Birkenmajer, K. \& Pécskay, Z., 2000. K-Ar dating of the Miocene andesite intrusions, Pieniny Mts, West Carpathians, Poland: a supplement. Studia Geologica Polonica, 47: 155-169.

Burtan, J., Chowaniec, J. \& Golonka, J., 1984. Preliminary results of studies on exotic carbonate rocks in the western part of the Polish Flysch Carpathians. Biuletyn Instytutu Geologicznego, 346: 147-159. (In Polish, English summary)

Chowaniec, J., 1989. Hydrogeologiczne warunki zasilania i przepływu wód podziemnych w utworach trzeciorzędowych Podhala między Zakopanem a Białym Dunajcem (Ph. D. Thesis), CAG PIG, Warszawa, 1-144. (In Polish only)

Chowaniec, J. \& Golonka, J., 1980. Wstępne wyniki badań egzotycznych skał węglanowych z fliszu podhalańskiego. Kwartalnik Geologiczny, 24: 966-967. (In Polish only)

Chowaniec, J. \& Golonka, J., 1981. The localities of inanimate nature worthy of protection lying in the region of the Podhale Flysch. Chronmy Przyrodę Ojczysta, 5: 5-12. (In Polish, English summary)

Chowaniec, J. \& Kępińska, B., 2003. Podhale geothermal system-selected issues. In: Golonka, J. \& Lewandowski, M. (Eds.): Geology, geophysics, geothermics and deep structure of the West Carpathians and their basement; Publications of the Institute of Geophysics Polish Academy of Sciences, M-28 (363): 13-23.

Chrustek, M. \& Golonka, J., 2005. Carpathian tectonics in the making - deformations and earthquakes in the Stare Bystre area (southern Poland). In: Doktor, M. \& Waśkowska-Oliwa, A. (Eds.): Geotourism - new dimensions in XXI century tourism and chances for future development. 2nd Internation Conference Geotour 2005, 22-24 September, Kraków: 16-18.
Cieszkowski, M., 1995. Utwory morskiego miocenu w rejonie Nowego Targu i ich znaczenie dla określenia czasu powstania śródgórskiego zapadliska Kotliny Orawsko-Nowotarskiej Kwartalnik AGH, Geologia, 21, 2: 153-168. (In Polish, English summary)

Ciulavu, D., \& Bertotti, G., 1994. The Transylvanian Basin and its Upper Cretaceous Substratum: ALCAPA II. Romanian Journal of Tectonics and Regional Geology, 75: 59-65.

Csontos, L., Nagymarosy, A., Horvat, F. \& Kováč, M., 1992. Tertiary evolution of the Intra-Carpathian area: a model. Tectonophysics, 208: 221241.

Csontos, L. \& Vörös, A., 2004. Mesozoic plate tectonic reconstruction of the Carpathian region. Palaeogeography, Palaeoclimatology, Palaeoecology, 210: 1-56.

Czerwiński, T., Klityński, W., Florek, R \& Stefaniuk, M., 2003. Regional magnetotelluric investigations in the Poilsh western Carpathians. Kwartalnik AGH, Geologia, 29, 3-4: 169-195. (In Polish, English summary)

Decker, K. \& Peresson H., 1996. Tertiary kinematics in the Alpine-Carpathian-Pannonian system: links between thrusting, transform faulting and crustal extension. In: Wessely, G. \& Liebl, W. (Eds.): Oil and Gas in Alpidic Thrustbelts and Basins of Central and Eastern Europe. Special Publications of the European Association of Geoscientists and Engineer, 5. Geological Society, London, pp. 17-21.

Dercourt, J., Ricou, L.E. \& Vrielynck, B. (Eds.): 1993. Atlas Tethys Paleoenvironmental Maps. Gauthier-Villars, Paris.

Dudziak, J., 1993. Age of the Podhale flysch (Palaeogene) at Kacwin, south of the Pieniny Klippen Belt, Carpathians, based on calcareous nannoplankton. Studia Geologica Polonica, 102: 159-176. (In Polish, English summary)

Dżułyński, S., 1996. Erosional and deformational structures in single sedimentary beds: a genetic commentary. Annales Societatis Geologorum Poloniae, 66: 101-189.

Dżułyński, S., 2001. Atlas of sedimentary structures from the Polish Flysch Carpathians. Material for $12^{\text {th }}$-Meeting of the Association of European Geological Societies, Institute of Geological Sciences, Jagiellonian University, Kraków: 5-132.

Garecka, M., 2005. Calcareous nanoplankton from the Podhale Flysch (Oligocene-Miocene, Inner Carpathians, Poland). Studia Geologica Polonica, 124: 353-369.

Gedl, P., 1999. Trophic conditions during the Early Oligocene stage of the development of the Podhale Flysch Basin (Inner Carpathians, Poland): a dinocyst record. Acta Palaeobotanica, Supplementum, 2: 279-291.

Gedl, P., 2000. Biostratigraphy and palaeoenvironment of the Podhale Palaeogene (Inner Carpathians, Poland) in the light of palynological studies. Part. I. Studia Geologica Polonica, 117: 69-154. (In Polish, English summary)

Golonka, J., 2000. Cambrian-Neogene Plate Tectonic Maps. Wydawnictwa Uniwersytetu Jagiellońskiego, Kraków, pp. 1-125.

Golonka, J., 2004. Plate tectonic evolution of the southern margin of Eurasia in the Mesozoic and Cenozoic. Tectonophysics, 381: 235-273.

Golonka, J., 2005. Mesozoic plate tectonics of the Inner Carpathians - rotational approach. Geolines, 19: 42-43.

Golonka, J., Oszczypko, N. \& Ślączka, A., 2000. Late Carboniferous-Neogene geodynamic evolution and paleogeography of the circum-Carparthian region and adjacent areas. Annales Societatis Geologorum Poloniae, 70: $107-136$.

Golonka, J., Krobicki, M., Pająk, J., Nguyen Van Giang \& Zuchiewicz W., 2006a. Global Plate Tectonics and Paleogeography of Southeast Asia. Faculty of Geology, Geophysics and Environmental Protection, AGH University of Science and Technology, Arkadia. pp. 1-128 pl.

Golonka, J., Gahagan, L., Krobicki, M., Marko, F., Oszczypko, N. \& Ślączka, A., 2006b. Plate-tectonic evolution and paleogeography of the CircumCarpathian region. In: Golonka, J. \& Picha, F.J. (Eds.): The Carpathians and their foreland: Geology and hydrocarbon Resources. American Association of Petroleum Geologists, Memoire, 84: 11-46.

Golonka, J., Aleksandrowski, J.P., Aubrecht, R., Chowaniec, J., Chrustek, M., Cieszkowski, M., Florek, R., Gawęda, A., Jarosiński, M., Kępińska, B., Krobicki, M., Lefeld, J., Lewandowski, M., Marko, F., Michalik, M., 
Oszczypko, N., Picha, F., Potfaj, M., Słaby, E., Ślączka, A., Stefaniuk, M., Uchman, A. \& Żelaźniewicz, A., 2005a. The Orava Deep Drilling Project and post-Palaeogene tectonics of the Northern Carpathians. Annales Societatis Geologorum Poloniae, 75: 211-248.

Golonka, J., Krobicki, M. \& Tłuczek, D., 2005b. Field Trip: Pieniny Klippen Belt and Polish Outer Carpathians. In: Doktor, M. \& Waśkowska-Oliwa, A. (Eds.): Geotourism - new dimensions in XXI century tourism and chances for future development. 2nd International Conference Geotour 2005, 22-24 September, Kraków: 129-160.

Gross, P. \& Köhler, E., 1993. Kritický pohl'ad na sedimentologické modely vnútrokarpatského paleogénu. Geologické práce, Správy, 97: 99-103. (In Slovak, English summary)

Gross, P., Köhler, E. \& Samuel, O., 1984. A new lithostratigraphical division of the Inner-Carpathian Paleogene. Geologicke Práce, Správy, 81: 103117. (In Slovak, English summary)

Hurai, V., Marko, F., Tokarski, A.K., Świerczewska, A., Kotulová, J. \& Biroň, A., 2006. Fluid inclusion evidence for deep burial of the Tertiary accretionary wedge of the Carpathians. Terra Nova, 18: 440-446.

Janočko, J. \& Kováč, M., 2003. Geotectonic background of origin of Western Carpathian sedimentary basins. In: Janočko, J. \& Elečko, M. (Eds.): Tectono-sedimentary evolution of Western Carpathian Tertiary Basin. Mineralia Slovaca, 36: 169-180.

Klimaszewski, M., 1952. Rzeźba Podhala. The relief of Podhale Basin. Czasopismo Geograficzne, 21-22: 237-250. (In Polish, English summary)

Kováč, M. \& Hók, J., 1993. The Central Slovak Fault System: Field evidence of a strike-slip. Geologica Carpathica, 44: 155-160.

Kováč, M., Nagymarosy, A., Oszczypko, N., Ślączka, A., Csontos, L., Marunteanu, M., Matenco, L. \& Márton. M., 1998. Palinspastic reconstruction of the Carpathian-Pannonian region during the Miocene, In: Rakús, M. (Eds.): Geodynamic development of the Western Carpathians. Geological Survey of Slovac Republic, Bratislava: 189-217.

Krawczyk, A., 1980. Some characteristic of the sedimentation processes of the Podhale Flysch. Rocznik Polskiego Towarzystwa Geologicznego, 50: 55-98. (In Polish, English summary)

Krobicki, M. \& Golonka, J., 2008. Geotouristical values of the Pieniny Klippen Belt and Tatra Mountains regions (Poland). Przeglad Geologiczny, 56, 8/1: 670-679.

Kulka, A., 1985. Arni sedimentological model in the Tatra Eocene. Kwartalnik Geologiczny, 29, 1: 31-64.

Kurz, W., Neubauer, F. \& Genser, J., 1996. Kinematics of Penninic nappes (Glockner Nappe and basement-cover nappes) in the Tauern Window (eastern Alps, Austria) during subduction and Penninic - Austroalpine collision. Eclogae geologicae Helvetiae, 89: 573-605.

Marko, F., 1996. Dynamic analysis of faulting in the Central-Carpathian Paleogene Basin, based on structural investigations in the Levočske Vrchy Mts. In: Sotak, J. (Eds.): Geological assessment of the Levočske vrchy Mts. - research report. Geofond, Bratislava: 399-462.

Marschalko, R., 1987. Paleogene submarine fans in the Central Carpathian Flysch. In: Stefanescu, M. (Eds.): Flysch deposits from the Harz, the Thuringian and Vogtlandian Slade Mountains in the Carpathians, the Balkans and the Caucasus (Bucharest): 51-64.

Márton, E., 2003. Western Carpathians: Tertiary paleomagnetism and rotations. In: Golonka, J. \& Lewandowski, M. (Eds.): Geology, geophysics, geothermics and deep structure of the West Carpathians and their basement. Publications of the Institute of Geophysics, Polish Academy of Sciences, Monographic Volume, 28 (363): 147-148.

Márton, E., Mastella, L. \& Tokarski, A., 1999. Large counterclockwise rotation of the Inner West Carpathian Paleogene flysch - evidence from paleomagnetic investigations of the Podhale Flysch (Poland). Physics and Chemistry of the Earth (A), 24, 8: 645-649.

Mastella, L., 1975. Flysch tectonics in the eastern part of the Podhale Basin (Carpathians, Poland). Rocznik Polskiego Towarzystwa Geologicznego, 45, 3/4: 361-401. (In Polish, English summary)

Mastella L. 1976. Consequent-structural landslides from the eastern Podhale. Biuletyn Geologiczny Uniwersytetu Warszawskiego, 18: 259-270.

Meszaros, N., 1996. Stratigrafia regiunii Turnu Rosu-Porcesti. (In Romanian). Convergente transilvane, 4: 42-45, Sibiu.

Michalik, A. \& Wieser, T., 1959. Tufity we fliszu podhalańskim. Kwartalnik Geologiczny, 3: 378-390. (In Polish only)

Michalik, M., Ladenberger, A., Skiba, M., Warzecha, M. \& Zych, B., 2005. Mineralogical characteristics of the Pieniny andesites. Mineralogical Society of Poland-Special Papers, 25: 333-336.

Mutti, E. \& Ricci Lucchi, F., 1975. Turbidite facies and facies associations.
In: Mutti, E. et al., (Eds.): Examples of turbidite facies associations from selected formations of the Northern Apennines. Field Trip A11, IX Int. Sedimentol. Congr., Nice, 21-36.

Nagymarosy, A. \& Báldi-Beke, M., 1993. The Szolnok unit and its probabale paleogeographic position. Tectonophysics, 226: 457-470.

Nemčok, M. \& Nemčok, J., 1994. Late Cretaceous deformation of the Pieniny Klippen Belt, West Carpathians. Tectonophysics, 239: 81-109.

Olszewska, B.W. \& Wieczorek, J., 1998. The Paleogene of the Podhale Basin (Polish Inner Carpathians) - micropalentological perspective. Przeglad Geologiczny, 46, 8/2: 721-728.

Oszczypko, N., 1999. From remnant ocean basin to collision-related foreland basin - a tentative history of the outer western Carpathians. Geologica Carpathica, 50: 161-165.

Ozimkowski, W., 1991. Geology of Podhale flysch in aerial photographs interpretation. Biuletyn Geologiczny Uniwersytetu Warszawskiego, 32: 93-118.

Passnedorfer, E., 1983. Jak powstaly Tatry. Wydawnictwa Geologiczne, Warszawa, 286p. (In Polish only)

Picha, F.J., 1996, Exploring for Hydrocarbons Under Thrust Belts A Challenging New Frontier in the Carpathians and Elsewhere. American Association of Petroleum Geologists, Buletin, 89: 1547-1564

Pieńkowski, G. \& Westfalewicz-Mogilska, E., 1986. Trace fossils from the Podhale Flysch Basin, Poland - an example of ecologically-based lithocorrelation. Lethaia, 19: 53-65.

Plašienka, D., Grecula, P., Putiš, M., Kováč, M. \& Hovorka, D., 1997. Evolution and structure of the Western Carpathians: an overview. In: Grecula, P., Hovorka, D. \& Putiš, M. (Eds.): Geological evolution of the Western Carpathians. Mineralia Slovaca, Monograph, Bratislava: 124.

Plašienka, D., Grecula, P., Putiš, M., Kováč, M. \& Hovorka, D., 2000. Evolution and structure of the Western Carpathians: an overview. In: Grecula, P., Hovorka, D. \& Putiš, M. (Eds.): Geological evolution of the Western Carpathians, Geocomplex. Bratislava, pp. 1-24.

Poprawa, P. \& Marynowski, L., 2005. Thermal history of the Podhale trough (northern part of the Central Carpathian Palaeogene basin) - preliminary results from 1-D maturity modelling. Mineralogical Society of Poland-Special Papers, 25: 352-355.

Ratschbacher, L., Frisch, W., Linzer, H.-G., Sperner, B., Meschede, M., Decker, K., Nemčok, M., Nemčok, J. \& Grygar, R., 1993. The Pieniny Klippen Belt in the Western Carpathians of northeastern Slovakia: structural evidence for transpression. Tectonophysics, 226: 471-483.

Radomski, A., 1958. The sedimentological character of the Podhale flysch. Acta Geologia Polonica, 8, 3: 335-409. (In Polish, English summary)

Roniewicz, P., 1969. Sedimentation of the Nummulite Eocene in the Tatra Mts. Acta Geologica Polonica, 19: 503-608. (In Polish, English summary)

Roniewicz, P., 1979. Paleogen Tatr i Podhala. In: Lefeld, J. (Eds.):, Przewodnik 51 Zjazdu Polskiego Towarzystwa Geologicznego, Zakopane; 13-15 września 1979. Wydawnictwa Geologiczne. Warszawa, pp. 57-72. (In Polish only)

Roniewicz, P. \& Pieńkowski, G., 1977. Trace fossils of the Podhale Flysch Basin. In: Crimes, T.P. \& Harper, J.C. (Eds.): Trace Fossils 2. Geological Journal, Special Issue, 9: 273-288.

Roniewicz, P. \& Westfalewicz-Mogilska, E., 1974. Tuffites in the Podhale Flysch (Western Carpathians). Bulletin of the Polish Academy of Sciences, Earth Sciences, 22: 37-43.

Săndulescu, M., Stefanescu, M., Butac, A., Patrut, I. \& Zaharescu, P. M., 1981. Genetical and structural relations between Flysch and Molasse (The East Carpathians Model). Institute of Geology and Geophysics, Romania, Bucharest, 95 pp.Shanmugam, G., 2000. 50 years of turbidite paradigm (1950s-1990s): deep-water processes and facies models - a critical perspective. Marine Petroleum Geology, 17: 285-342.

Sokołowski, S., 1973. Geology of Palaeogene and Mesozoic basement of the Podhale Trough southern limb in the column of the Zakopane deep borehole. Biuletyn Instytutu Geologicznego, 265: 5-103. (In Polish, English summary)

Soták, J. \& Janočko, J., 2001. Central-Carpathian Paleogene Basin - an outline to sedimentology, sequence stratigraphy and basin history. In: Janočko, J. \& Soták, J. (Eds.): Sedimentary sequences and depositional systems of the Central-Carpathian Paleogene Basin. Guidebook to IAS field trip, Slovakia 2001; October 8-12, 2001, Slovakia, pp. 1-32.

Soták, J., Pereszlényi, M., Marschalko, R., Milička, J. \& Stárek, D., 2001. Sedimentology and hydrocarbon habitat of the submarine-fan deposits 
of the Central Carpathian Paleogene Basin (NE Slovakia). Marine and Petroleum Geology, 18: 87-114.

Sperner, B., 1996. Computer programs for the kinematic analysis of brittle deformation structures and the Tertiary tectonic evolution of the Western Carpathians (Slovakia). Tübinger Geowissenschaftliche Arbeiten, 27: $1-120$.

Sperner, B., Ratschbacher, L. \& Nemčok, M., 2002. Interplay between subduction retreat and lateral extrusion: Tectonics of the Western Carpathians. Tectonics, 21: 1051.

Ślączka, A., 1996. Oil and gas in the northern Carpathians. Wessely, G. \& Liebl, W. (Eds.): Oil and Gas in Alpidic Thrustbelts and Basins of Central and Eastern Europe. Special Publications of the European Association of Geoscientists and Engineer, 5. Geological Society, London, pp. 187-195.

Środoń, J., 2007. History of the Podhale flysch basin revealed by K-Ar and AFT dating and XRD study of clay minerals. Mineralogia Polonica Special Papers, 31: 329-335.

Środoń, J., Kotarba, Clauer, N. \& Wójtowicz, A., 2005. Diagenetic history of Podhale basin and the sedimentary cover of the Tatras. Mineralogical Society of Poland - Special Papers, 25: 372-375.

Środoń, J., Kotarba, M., Biroń, A., Such, P., Clauer, N. \& Wójtowicz, A., 2006. Diagenetic history of the Podhale-Orava basin and the underlying Tatra sedimentary structural units (Western Carpathians): evidence from XRD and K-Ar of illite-smectite. Clay Minerals, 41: 747-770.

Tari, G., Báldi, T. \& Báldi-Beke, M., 1993. Paleogene retroarc flexural basin beneth the Neogene Pannonian Basin: a geodynamic model. Tectonophysics, 226: 433-455.
Trua, T., Serri, G., Birkenmajer, K. \& Pécskay, Z., 2006. Geochemical and $\mathrm{Sr}-\mathrm{Nd}-\mathrm{Pb}$ isotopic compositions of Mts pieniny dykes and sills (West Carpathians): evidence for melting in the lithospheric mantle. Lithos, 90: 57-76.

Westfalewicz-Mogilska, E., 1986. Nowe spojrzenie na genezę osadów fliszu podhalańskiego. Przeglad Geologiczny, 12: 690-698. (In Polish only)

Wieczorek, J., 1989. Model Hecho dla fliszu podhalańskiego? Przeglad Geologiczny, 9: 419-423. (In Polish only)

Wieczorek, J., 1995. Kritický pohl'ad na sedimentologické modely vnútrokarpatského paleogenu: reply. Geologické práce, Správy, 100: 117118.

Wieczorek, J. \& Barbacki, A., 1997. Przekrój geologiczny przez nieckę podhalańską i jej podłoże na podstawie danych sejsmicznych i wiertniczych; implikacje dla geotermii. Przeglad Geologiczny, 45, 7: 715-720. (In Polish only)

Zuchiewicz, W., 1998. Quaternary tectonics of the Outer West Carpathians, Poland. Tectonophysics, 297: 121-132.

Zuchiewicz, W., Neotectonics: Polish Carpathians (http://www.uj.edu.pl/ ING/neotectonics/nk.pdf)

Żytko, K., Zając, R., Gucik, S., Ryłko, W., Oszczypko, N., Garlicka, I., Nemčok, J., Eliáš, M., Menčik, E. \& Stránik, Z., 1989. Map of the tectonic elements of the Western Outer Carpathians and their foreland. In: Poprawa, D. \& Nemčok, J. (Eds.): Geological Atlas of the Western Outer Carpathians and their Foreland. Państwowy Instytut Geologiczny, Warszawa/GUDŠ Bratislava/Uug Praha 